\title{
Studying the Hydrological Conditions for Origin of First Organic Forms of Life in Hot Mineral Water with HDO
}

\author{
Ignat Ignatov $^{1^{*}} \quad$ Oleg Mosin ${ }^{2}$ \\ 1. DSc, Professor, Scientific Research Center of Medical Biophysics (SRCMB), \\ N. Kopernik Street, 32, Sofia 1111, Bulgaria \\ 2. $\mathrm{PhD}$ (Chemistry), Biotechnology Department, Moscow State University of Applied Biotechnology, \\ Talalikhina Street, 33, Moscow 109316, Russian Federation
}

\begin{abstract}
Three factors as isotopic composition, the temperature and $\mathrm{pH}$ value of water were analyzed in experiments with prognosis of primary hydrosphere and possible conditions for origin of first organic forms in hot mineral water with HDO. For this aim the authors performed experiments with hot mineral and seawater from Bulgaria, and water with varying content of deuterium using IR-, and DNES-spectroscopy. As model systems were used cactus juice of Echinopsis pachanoi and Mediterranean jellyfish Cotylorhiza tuberculata. There were discussed the reactions of condensation and dehydration occurring in alkaline aqueous solutions at $65-95{ }^{\circ} \mathrm{C}$ and $\mathrm{pH}=9-10$, resulting in synthesis from separate molecules larger organic molecules as polymers and short polypeptides, as well as were predicted the possible mechanisms of the deuterium accumulation in form of HDO in hot water. It was shown that hot alkaline mineral water with temperature from $+65{ }^{\circ} \mathrm{C}$ to $+95{ }^{\circ} \mathrm{C}$ and $\mathrm{pH}$ value from 9 to 11 is more suitable for the origination of life and living matter than other analyzed water samples. The $\mathrm{pH}$ value of seawater on contrary is limited to the range of 7.5 to 8.4 units. Two common local maximums were observed in the IR-spectra of jellyfish and seawater, which were more pronouncedly expressed in IR-spectra of jellyfish. In hot mineral waters the local maximums in IR-spectra are more manifested compared to the local maximums obtained in IR-spectra of the same water at a lower temperature. The difference in the local maximums from $+20{ }^{\circ} \mathrm{C}$ to +95 ${ }^{0} \mathrm{C}$ at each $5{ }^{\circ} \mathrm{C}$ according to Student $t$-criterion $-\mathrm{p}<0.05$. These data indicate that the origination of life and living matter depends on the structure and physical chemical properties of water, as well as its temperature and $\mathrm{pH}$ value. Keywords: deuterium, hydrosphere, evolution, origin of life, IR-spectroscopy.
\end{abstract}

\section{Introduction}

Previous biological experiments with $\mathrm{D}_{2} \mathrm{O}$ and structural-conformational studies with deuterium substituted molecules, performed by us, enable to modelling conditions under which the first living forms of life might be evolved (Ignatov \& Mosin, 2013a; Ignatov \& Mosin, 2013b; Ignatov \& Mosin, 2013c). The content of deuterium in hot mineral water may be increased due to the physical chemical processes of the deuterium accumulation. It can be presumed that primary water might contain more deuterium at early stages of evolution of first living structures, and deuterium was distributed non-uniformly in the hydrosphere and atmosphere (Ignatov \& Mosin, 2012). The primary reductive atmosphere of the Earth consisted basically of gas mixture $\mathrm{CO}, \mathrm{H}_{2}, \mathrm{~N}_{2}, \mathrm{NH}_{3}, \mathrm{CH}_{4}$, lacked $\mathrm{O}_{2}-\mathrm{O}_{3}$ layer protecting the Earth surface from rigid short-wave solar radiation carrying huge energy capable to cause radiolysis and photolysis of water. The processes accompanying accumulation of deuterium in the hydrosphere are solar radiation, volcanic geothermal processes and electric discharges in the atmosphere. These natural processes could lead to the enrichment of the hydrosphere by deuterium in the form of HDO which evaporates more slowly than $\mathrm{H}_{2} \mathrm{O}$, and condenses faster. If this is true, this is a significant fact regarding thermal stability of deuterated macromolecules in the preservation of life under thermal conditions, because chemical bonds with participation of deuterium are somewhat stronger than those ones formed of hydrogen.

Natural prevalence of deuterium makes up approximately $0.015-0.020$ at.\%, and depends strongly on the uniformity of substance and the total amount of matter formed in the course of early Galaxy evolution (Linsky, 2007). Constant sources of deuterium are explosions of nova stars and thermonuclear processes frequently occurring inside the stars. Perhaps this explains the fact that the total amount of deuterium is slightly increased in the period of global warming.

The gravitational field of the Earth is insufficiently strong for the retaining of lighter hydrogen, and our planet is gradually losing hydrogen as a result of its dissociation into interplanetary space. Hydrogen evaporates faster than heavy deuterium, which can be collected by the hydrosphere. Therefore, as a result of this natural process of fractionation of H/D isotopes throughout the process of Earth evolution there should be an accumulation of deuterium in the hydrosphere and surface waters, while in the atmosphere and in water vapour deuterium content tends to be low. Thus, on the planet there occurs a natural process of separation of $\mathrm{H}$ and $\mathrm{D}$ isotopes, playing an essential role in the maintenance of life on the planet.

The second point regards the influence of temperature on the life processes. Recent studies have shown that the most favourable for the origin of life and living matter seem to be hot alkaline mineral waters interacting with $\mathrm{CaCO}_{3}$ (Ignatov, 2010; Ignatov \& Mosin, 2013d). According to the law for conservation of energy the 
process of self-organization of primary organic forms in water solutions may be supported by thermal energy of magma, volcanic activity and solar radiation. According to J. Szostak, the accumulation of organic compounds in open lakes is more possible compared to the ocean (Szostak, 2011). Life began near a hydrothermal vent: an underwater spout of hot water. Geothermal activity gives more opportunities for the origination of life. In 2009 A. Mulkidjanian and M. Galperin demonstrate that the cell cytoplasm contains potassium, zinc, manganese and phosphate ions, which are not particularly widespread in the sea aquatorium (Mulkidjanian \& Galperin, 2009). J. Trevors and G. Pollack proposed in 2005 that the first cells on the Earth assembled in a hydrogel environment (Trevors \& Pollack, 2005). Gel environments are capable of retaining water, oily hydrocarbons, solutes, and gas bubbles, and are capable of carrying out many functions, even in the absence of a membrane. Hydrocarbons are an organic compounds consisting entirely of hydrogen and carbon. The previous data showed that the origination of living matter most probably occurred in hot mineral water (Ignatov, 2012). This might occurred in ponds and hydrothermal vents in seawater or hot mineral water. An indisputable proof of this is the presence of stromatolites fossils. They lived in warm and hot water in zones of volcanic activity, which could be heated by magma and seem to be more stable than other first marine organisms.

The purpose of the research was studying the conditions of primary hydrosphere (temperature, $\mathrm{pH}$, isotopic composition) for possible processes for origin of life and living matter in hot mineral water. Various samples of water from Bulgaria were studied within the frames of the research.

\section{Material and Methods \\ 2.1. Objects of Studying \\ 2.1.1. Biological Objects}

The objects of the study were various microorganisms, realizing methylotrophic, chemoheterotrophic, photoorganotrophic, and photosynthetic ways of assimilation of carbon substrates. The initial strains were obtained from the State Research Institute of Genetics and Selection of Industrial Microorganisms (Moscow, Russia):

1. Brevibacterium methylicum B-5652, a leucine auxotroph Gram-positive strain of facultative methylotrophic bacterium, L-phenylalanine producer, assimilating methanol via the $\mathrm{NAD}^{+}$dependent methanol dehydrogenase variant of ribulose-5-monophosphate cycle (RuMP) of carbon fixation.

2. Bacillus subtilis B-3157, a polyauxotrophic for histidine, tyrosine, and adenine, and uracil spore-forming aerobic Gram-positive chemoheterotrophic bacterium, inosine producer, realizing hexose-6-mono-phosphate (GMP) cycle of carbohydrates assimilation.

3. Halobacterium halobium ET-1001, photo-organotrophic carotenoids-containing strain of extreme halobacteria, synthesizing the photochrome transmembrane protein bacteriorhodopsin.

4. Chlorella vulgaris $B-8765$, photosynthesizing single-cell green algae.

5. Mediterranean jellyfish Cotylorhiza tuberculata (Chalkida (Greece), Aegean Sea).

\subsubsection{Water Samples}

The research by the IR-spectrometry (DNES-method) was carried out with samples of water taken from various water springs of Bulgaria:

1 - Mineral water (Rupite, Bulgaria);

2 - Seawater (Varna resort, Bulgaria);

3 - Mountain water (Teteven, Bulgaria);

5 - Deionized water (the control).

6 - Water with varying deuterium content (HDO).

As model systems were used cactus juice of Echinopsis pachanoi and Mediterranean jellyfish Cotylorhiza tuberculata (Chalkida (Greece), Aegean Sea).

\subsection{Chemicals}

For preparation of growth media was used $\mathrm{D}_{2} \mathrm{O}(99.9$ atom. $\%),{ }^{2} \mathrm{HCl}\left(95.5\right.$ atom. $\%$ ) and $\mathrm{CD}_{3} \mathrm{OD}(97.5$ atom\% $\left.{ }^{2} \mathrm{H}\right)$, purchased from the "Isotope" Russian Research Centre (St. Petersburg, Russian Federation). Inorganic salts and $D$ - and $L$-glucose ("Reanal", Hungary) were preliminary crystallized in $\mathrm{D}_{2} \mathrm{O}$ and dried in vacuum before using. $\mathrm{D}_{2} \mathrm{O}$ was distilled over $\mathrm{KMnO}_{4}$ with the subsequent control of isotope enrichment by ${ }^{1} \mathrm{H}-\mathrm{NMR}-$ spectroscopy on a Brucker WM-250 device ("Brucker", Germany) (working frequency: $70 \mathrm{MHz}$, internal standard: $\mathrm{Me}_{4} \mathrm{Si}$ ). According to ${ }^{1} \mathrm{H}-\mathrm{NMR}$, the level of isotopic purity of growth media usually was by $\sim 8-10$ atom\% lower than the isotope purity of the initial $\mathrm{D}_{2} \mathrm{O}$.

\subsection{Adaptation Studies}

The initial microorganisms were modified by adaptation to deuterium by plating individual colonies onto $2 \%$ $(w / v)$ agarose growth media with stepwise increasing gradient of $\mathrm{D}_{2} \mathrm{O}$ concentration and subsequent selection of individual cell colonies stable to the action of $\mathrm{D}_{2} \mathrm{O}$. As a source of deuterated growth substrates for the growth of chemoheterotrophic bacteria and chemoorganoheterotrophic bacteria was used the deuterated biomass of 
facultative methylotrophic bacterium B. methylicum, obtained via a multi-stage adaptation on solid 2\% (w/v) agarose M9 media with an increasing gradient of $\mathrm{D}_{2} \mathrm{O}$ (from $0,24.5,49.0,73.5$ up to $98 \%$ (v/v) $\mathrm{D}_{2} \mathrm{O}$ ). Raw deuterated biomass (output, 100 gram of wet weight per 1 liter of liquid culture) was suspended in $100 \mathrm{ml}$ of 0.5 $\mathrm{N} \mathrm{DCl}$ (in $\mathrm{D}_{2} \mathrm{O}$ ) and autoclaved for 30-40 min at $0.8 \mathrm{~atm}$. The suspension was neutralized with $0.2 \mathrm{~N} \mathrm{KOH}$ (in $\left.\mathrm{D}_{2} \mathrm{O}\right)$ to $\mathrm{pH}=7.0$ and used as a source of growth substrates while adaptation and growing the chemoheterotrophic bacterium B. subtilis and the photo-organotrophic Halobacterium H. halobium.

\subsection{Growth Media}

The following growth media were used (concentration of components are given in $\mathrm{g} / \mathrm{l}$ ):

1. Minimal salt medium M9 for growth of the facultative methanol assimilating methylotrophic bacterium $B$. methylicum $B-5662$, supplemented with $2 \%(\mathrm{v} / \mathrm{v}) \mathrm{CD}_{3} \mathrm{OD}$ and increasing gradient of $\mathrm{D}_{2} \mathrm{O}$ concentration from 0 ; $24.5 ; 49.0 ; 73.5$ up to $98 \%$ (v/v) $\mathrm{D}_{2} \mathrm{O}: \mathrm{KH}_{2} \mathrm{PO}_{4}-3 ; \mathrm{Na}_{2} \mathrm{HPO}_{4}-6 ; \mathrm{NaCl}-0.5 ; \mathrm{NH}_{4} \mathrm{Cl}-1 ; L$-leucine -0.01 .

2. Hydrolysated medium HM1 for growth of the aerobic Gram-positive chemoheterotrophic bacterium B. subtilis $B-3157$, based on $\mathrm{D}_{2} \mathrm{O}(89-90$ atom\% D) and $2 \%(\mathrm{w} / \mathrm{v})$ hydrolysate of deuterated biomass of $B$. methylicum B5662 as a source of deuterium-labeled growth substrates: $L$-glucose -120 ; hydrolysate of deuterated biomass of B. methylicum - 20, $\mathrm{NH}_{4} \mathrm{NO}_{3}-20 ; \mathrm{MgSO}_{4} \cdot 7 \mathrm{H}_{2} \mathrm{O}-10 ; \mathrm{CaCO}_{3}-20$; adenine, and uracil - 0.01. As a control was used protonated medium containing $2 \%(\mathrm{w} / \mathrm{v})$ yeast protein-vitamin concentrate (PVC).

3. Hydrolysated medium HM2 for the growth of the extreme aerobic halobacterium Halobacterium halobium ET-1001 (based on 99.9 atom\% $\mathrm{D}_{2} \mathrm{O}$ ): $\mathrm{NaCl}-250 ; \mathrm{MgSO}_{4} 7 \mathrm{H}_{2} \mathrm{O}-20 ; \mathrm{KCl}-2 ; \mathrm{CaCl}_{2} \cdot 6 \mathrm{H}_{2} \mathrm{O}-0.065$; sodium citrate - 0.5; hydrolysate of deuterated biomass of B. methylicum B-5662-20; biotin $-1 \cdot 10^{-4}$; folic acid $-1.5^{\prime} 10^{-}$ 4 , vitamin $\mathrm{B}_{12}-2 \cdot 10^{-5}$ ).

4. Tamiya medium for the growth of the photosynthetic green microalgae C. vulgaris $B-8765$ (based on 99.9 atom\% $\left.\mathrm{D}_{2} \mathrm{O}\right): \mathrm{KNO}_{3}-5.0 ; \mathrm{MgSO}_{4} 7 \mathrm{H}_{2} \mathrm{O}-2.5 ; \mathrm{KH}_{2} \mathrm{PO}_{4}-1.25 ; \mathrm{FeSO}_{4}-0.003 ; \mathrm{MnSO}_{4} 2 \mathrm{H}_{2} \mathrm{O}-3 \cdot 10^{-4}$; $\left.\mathrm{CaCl}_{2} \cdot 6 \mathrm{H}_{2} \mathrm{O}-0.065 ; \mathrm{ZnSO}_{4} \cdot 7 \mathrm{H}_{2} \mathrm{O}-4 \cdot 10^{-5} ; \mathrm{CuSO}_{4} \cdot 5 \mathrm{H}_{2} \mathrm{O}-5 \cdot 10^{-5}, \mathrm{CoCl}_{2} 6 \mathrm{H}_{2} \mathrm{O}-5 \cdot 10^{-6}\right)$.

\subsection{Growth Conditions}

The cells were grown in $500 \mathrm{ml}$ Erlenmeyer flasks containing $100 \mathrm{ml}$ of the growth medium at $32-34{ }^{0} \mathrm{C}$ and vigorously aerated on an orbital shaker Biorad ("Biorad Labs", Poland). Photo-organotrophic bacteria and green algae were grown at illumination by fluorescent monochromatic lamps LDS-40-2 (40 W) ("Alfa-Electro", Russia). Growing of microalgae $C$. vulgaris was carried out at $32{ }^{\circ} \mathrm{C}$ in a photoreactor with $\mathrm{CO}_{2}$ bubbling. The bacterial growth was monitored on the ability to form individual colonies on the surface of solid $2 \%$ (w/v) agarose media, as well as on the optical density of the cell suspension measured on a Beckman DU-6 spectrophotometer ("Beckman Coulter", USA) at $\lambda=620 \mathrm{~nm}$. After 6-7 days the cells were harvested and separated by centrifugation (10000 g, $20 \mathrm{~min}$ ) on T-24 centrifuge ("Heracules", Germany). The biomass was washed with $\mathrm{D}_{2} \mathrm{O}$ and extracted with a mixure of organic solvents: chloroform-methanol-acetone $=2: 1: 1, \%$ $(\mathrm{v} / \mathrm{v})$ for isolating lipids and pigments. The resulting precipitate (10-12 $\mathrm{mg}$ ) was dried in vacuum and used as a protein fraction, while the liquid extract - as a lipid fraction.

\subsection{IR-Spectroscopy}

IR-spectra of water samples were registered on Brucker Vertex ("Brucker", Germany) Fourier-IR spectrometer (spectral range: average IR $-370-7800 \mathrm{~cm}^{-1}$; visible $-2500-8000 \mathrm{~cm}^{-1}$; permission $-0.5 \mathrm{~cm}^{-1}$; accuracy of wave number $-0.1 \mathrm{~cm}^{-1}$ on $2000 \mathrm{~cm}^{-1}$ ) and on Thermo Nicolet Avatar 360 Fourier-transform IR (M. Chakarova)

\subsection{DNES-Spectroscopy}

The research was made with the method of differential non-equilibrium spectrum (DNES). The device measures the angle of evaporation of water drops from $72{ }^{0}$ to $0{ }^{\circ}$. As the main estimation criterion was used the average energy $\left(\Delta \mathrm{E}_{\mathrm{H} \ldots \mathrm{O}}\right)$ of hydrogen $\mathrm{O} \ldots . . \mathrm{H}$-bonds between $\mathrm{H}_{2} \mathrm{O}$ molecules in water's samples. The spectra of water were measured in the range of energy of hydrogen bonds $0,08-0,1387 \mathrm{eV}$ with using a specially designed computer program.

\subsection{High-Frequency Coronal Electric Discharge Experiments}

A device for high-frequency coronal electric discharge was used in this study, constructed by I. Ignatov and Ch. Stoyanov (Ignatov \& Mosin, 2013e). The frequency of the applied saw-tooth electric voltage was $15 \mathrm{kHz}$, and the electric voltage $-15 \mathrm{KV}$. The electric discharge was obtained using a transparent firm polymer electrode on which a liquid sample of water $(2-3 \mathrm{~mm})$ was placed. The spectral range of the photons released upon electric discharge was from $\lambda=400$ to $\lambda=490 \mathrm{~nm}$ and from $\lambda=560$ to $\lambda=700 \mathrm{~nm}$.

\subsection{Amino Acid Analysis}

The amino acids of the hydrolyzed biomass were analyzed on a Biotronic LC-5001 $(230 \times 3.2)$ column 
("Eppendorf-Nethleler-Hinz", Germany) with a UR-30 sulfonated styrene resin ("Beckman-Spinco", USA) as a stationary phase; the temperature $-20 \pm 25{ }^{0} \mathrm{C}$; the mobile phase $-0.2 \mathrm{~N}$ sodium-citrate buffer $(\mathrm{pH}=2.5)$; the granule diameter - $25 \mu \mathrm{m}$; working pressure - 50-60 atm; the eluent input rate $-18.5 \mathrm{ml} / \mathrm{h}$; the ninhydrin input rate $-9.25 \mathrm{ml} / \mathrm{h}$; detection at $\lambda=570$ and $\lambda=440 \mathrm{~nm}$ (for proline).

\subsection{Analysis of Carbohydrates}

Carbohydrates were analyzed on a Knauer Smartline chromatograph ("Knauer", Germany) equipped with a Gilson pump ("Gilson Inc.", USA) and a Waters K 401 refractometer ("Water Associates", USA) using Ultrasorb $\mathrm{CN}$ column $(250 \times 10 \mathrm{~mm})$ as a stationary phase; the temperature $-20 \pm 25{ }^{0} \mathrm{C}$; the mobile phase acetonitrile-water $(75: 25, \%(\mathrm{w} / \mathrm{w})$; the granule diameter $-10 \mu \mathrm{m}$; the input rate $-0.6 \mathrm{ml} / \mathrm{min}$.

\subsection{Analysis of Fatty Acids}

Fatty acids were analyzed on a Beckman Gold System (USA) chromatograph $(250 \times 4.6 \mathrm{~mm})$, equiped with Model 126 UV-Detector (USA), $20 \pm 25{ }^{\circ} \mathrm{C}$. Stationary phase - Ultrasphere ODS $5 \mu \mathrm{m}$; mobile phase - linear gradient of $5 \mathrm{mM} \mathrm{KH}{ }_{2} \mathrm{PO}_{4}$-acetonitrile; elution rate $-0.5 \mathrm{ml} / \mathrm{min}$, detection at $\lambda=210 \mathrm{~nm}$.

\subsection{Mass Spectrometry}

For evaluation of deuterium enrichment levels EI and FAB mass spectrometry was used. EI mass spectra were recorded on MB-80A device ("Hitachi", Japan) with double focusing (the energy of ionizing electrons - $70 \mathrm{eV}$; the accelerating voltage $-8 \mathrm{kV}$; the cathode temperature $-180-200{ }^{\circ} \mathrm{C}$ ) after amino acid modification into methyl esters of $\mathrm{N}$-5-dimethylamino(naphthalene)-1-sulfonyl (dansyl) amino acid derivatives according to an earlier elaborated protocol (Mosin et al., 1998). FAB-mass spectra were recorded on a VG-70 SEQ chromatograph ("Fisons VG Analytical", USA) equipped with a cesium $\mathrm{Cs}^{+}$source on a glycerol matrix with accelerating voltage $5 \mathrm{kV}$ and ion current $0.6-0.8 \mathrm{~mA}$. Calculation of deuterium enrichment of the molecules was carried out using the ratio of contributions of molecular ion peaks of deuterated compounds extracted on $\mathrm{D}_{2} \mathrm{O}$-media relative to the control obtained on $\mathrm{H}_{2} \mathrm{O}$.

\subsection{Scanning Electron Microscopy (SEM)}

SEM was carried out on JSM 35 CF (JEOL Ltd., Korea) device, equiped with SE detector, thermomolecular pump, and tungsten electron gun (Harpin type W filament, DC heating); working pressure $-10^{-4} \mathrm{~Pa}\left(10^{-6} \mathrm{Torr}\right)$; magnification $-\times 150.000$, resolution $-3.0 \mathrm{~nm}$, accelerating voltage $-1-30 \mathrm{kV}$; sample size $-60-130 \mathrm{~mm}$.

\section{Results and Discussion}

\subsection{Isotopic Effects of Deuterium}

The most interesting biological phenomenon is the ability of some microorganisms to grow on heavy water $\left(\mathrm{D}_{2} \mathrm{O}\right)$ media in which all hydrogen atoms are replaced with deuterium (Ignatov \& Mosin, 2013a; Ignatov \& Mosin, 2013b; Kushner et al., 1999).

The average ratio of $\mathrm{D} /{ }^{1} \mathrm{H}$ in nature makes up approximately 1:5700 (Lis et al., 2008). In natural waters, the deuterium is distributed irregularly: from $0.02-0.03 \mathrm{~mol} \%$ for river water and sea water, to 0.015 mol.\% for water of Antarctic ice - the most purified from deuterium natural water containing in 1.5 times less deuterium than that of seawater. According to the international SMOW standard isotopic shifts for $\mathrm{D}$ and ${ }^{18} \mathrm{O}$ in sea water: $\mathrm{D} /{ }^{1} \mathrm{H}=(155.76 \pm 0.05) \cdot 10^{-6}(155.76 \mathrm{ppm})$ and ${ }^{18} \mathrm{O} /{ }^{16} \mathrm{O}=(2005.20 \pm 0.45) \cdot 10^{-6}(2005 \mathrm{ppm})$. For SLAP standard isotopic shifts for $\mathrm{D}$ and ${ }^{18} \mathrm{O}$ in seawater make up $\mathrm{D} /{ }^{1} \mathrm{H}=89 \cdot 10^{-6}(89 \mathrm{ppm})$ and for a pair of ${ }^{18} \mathrm{O} /{ }^{16} \mathrm{O}=$ $1894 \cdot 10^{-6}(1894 \mathrm{ppm})$. In surface waters, the ratio $\mathrm{D} /{ }^{1} \mathrm{H}=\sim(1.32-1.51)^{\cdot} 10^{-4}$, while in the coastal seawater $\sim(1.55-1.56) \cdot 10^{-4}$. The natural waters of CIS countries are characterized by negative deviations from SMOW standard to $(1.0-1.5) \cdot 10^{-5}$, in some places up to $(6.0-6.7) \cdot 10^{-5}$, but however there are also observed positive deviations at $2.0 \cdot 10^{-5}$.

The chemical structure of $\mathrm{D}_{2} \mathrm{O}$ molecule is analogous to that one for $\mathrm{H}_{2} \mathrm{O}$, with small differences in the length of the covalent $\mathrm{H}-\mathrm{O}$-bonds and the angles between them. The molecular mass of $\mathrm{D}_{2} \mathrm{O}$ exceeds on $10 \%$ that one for $\mathrm{H}_{2} \mathrm{O}$. The difference in nuclear masses stipulates the isotopic effects, which may be sufficiently essential for the ${ }^{1} \mathrm{H} / \mathrm{D}$ pair (Lobishev \& Kalinichenko, 1978). As a result, physical-chemical properties of $\mathrm{D}_{2} \mathrm{O}$ differ from $\mathrm{H}_{2} \mathrm{O}: \mathrm{D}_{2} \mathrm{O}$ boils at $101.44{ }^{0} \mathrm{C}$, freezes at $3.82{ }^{0} \mathrm{C}$, has maximal density at $11.2{ }^{0} \mathrm{C}\left(1.106 \mathrm{~g} / \mathrm{cm}^{3}\right)$ (Vertes, 2004). In mixtures of ${ }^{2} \mathrm{H}_{2} \mathrm{O}$ with $\mathrm{H}_{2} \mathrm{O}$ the isotopic exchange occurs with high speed with the formation of semi-heavy water $\left({ }^{1} \mathrm{HDO}\right): \mathrm{D}_{2} \mathrm{O}+\mathrm{H}_{2} \mathrm{O}={ }^{1} \mathrm{HDO}$. For this reason deuterium presents in smaller content in aqueous solutions in form of ${ }^{1} \mathrm{HDO}$, while in the higher content - in form of $\mathrm{D}_{2} \mathrm{O}$. The chemical reactions in $\mathrm{D}_{2} \mathrm{O}$ are somehow slower compared to $\mathrm{H}_{2} \mathrm{O}$. $\mathrm{D}_{2} \mathrm{O}$ is less ionized, the dissociation constant of $\mathrm{D}_{2} \mathrm{O}$ is smaller, and the solubility of the organic and inorganic substances in $\mathrm{D}_{2} \mathrm{O}$ is smaller compared to these ones in $\mathrm{H}_{2} \mathrm{O}$ (Mosin, 1996). Due to isotopic effects the hydrogen bonds with the participation of deuterium are slightly stronger than 
those ones formed of hydrogen.

Numerous studies carried out by us with various biological objects in $\mathrm{D}_{2} \mathrm{O}$, proved that when biological objects being exposed to water with different deuterium content, their reaction varies depending on the isotopic composition of water (the content of deuterium in water) and magnitude of isotope effects determined by the difference of constants of chemical reactions rates $\mathrm{k}_{\mathrm{H}} / \mathrm{k}_{\mathrm{D}}$ in $\mathrm{H}_{2} \mathrm{O}$ and $\mathrm{D}_{2} \mathrm{O}$. The maximum kinetic isotopic effect observed at ordinary temperatures in chemical reactions leading to rupture of bonds involving hydrogen and deuterium atoms lies in the range $\mathrm{k}_{\mathrm{H}} / \mathrm{k}_{\mathrm{D}}=5-8$ for $\mathrm{C}-\mathrm{H}$ versus $\mathrm{C}-\mathrm{D}, \mathrm{N}-\mathrm{D}$ versus $\mathrm{N}-\mathrm{D}$, and O-D versus bonds (Mosin et al., 2012; Mosin \& Ignatov, 2012a; Mosin \& Ignatov, 2012b). Isotopic effects have an impact not only on the physical and chemical properties of deuterated macromolecules in which $\mathrm{H}$ atoms are substituted with $\mathrm{D}$ atoms, but also on the biological behavior of biological objects in $\mathrm{D}_{2} \mathrm{O}$. Experiments with $\mathrm{D}_{2} \mathrm{O}$ have shown, that green-blue algae is capable to grow on $70 \%(\mathrm{v} / \mathrm{v}) \mathrm{D}_{2} \mathrm{O}$, methylotrophic bacteria $-75 \%$ $(\mathrm{v} / \mathrm{v}) \mathrm{D}_{2} \mathrm{O}$, chemoheterotrophic bacteria $-82 \%(\mathrm{v} / \mathrm{v}) \mathrm{D}_{2} \mathrm{O}$, and photo-organotrophic halobacteria $-95 \%(\mathrm{v} / \mathrm{v})$ $\mathrm{D}_{2} \mathrm{O}$.

In the course of the experiment were obtained adapted to the maximum concentration of $\mathrm{D}_{2} \mathrm{O}$ cells belonging to different taxonomic groups of microorganisms, realizing methylotrophic, chemoheterotrophic, photo-organotrophic and photosynthetic pathways of assimilation of carbon substrata, as facultative methylotrophic bacterium B. methylicum, chemoheterotrophic bacterium B. subtilis, halobacterium $H$. halobium and green algae $C$. vulgaris.

Our studies indicated that the ability of adaptation to $\mathrm{D}_{2} \mathrm{O}$ for different taxonomic groups of microorganisms is different, and stipulated by taxonomic affiliation, metabolic characteristics, pathways of assimilation of substrates, as well as by evolutionary niche occupied by the object. Thus, the lower the level of evolutionary organization of the organism, the easier it adapted to the presence of deuterium in growth media. Thus, most primitive in evolutionary terms (cell membrane structure, cell organization, resistance to environmental factors) of the studied objects are photo-organotrophic halobacteria related to archaebacteria, standing apart from both prokaryotic and eukaryotic microorganisms, exhibiting increased resistance to $\mathrm{D}_{2} \mathrm{O}$ and practically needed no adaptation to $\mathrm{D}_{2} \mathrm{O}$, contrary to green algae, which, being eukaryotes, are the more difficult adapted to $\mathrm{D}_{2} \mathrm{O}$ and, therefore, exhibit inhibition of growth at $70-75 \%(\mathrm{v} / \mathrm{v}) \mathrm{D}_{2} \mathrm{O}$.

The composition of growth media evidently also plays an important role in process of adaptation to $\mathrm{D}_{2} \mathrm{O}$, because the reason of inhibition of cell growth and cell death can be changes of the parity ratio of synthesized metabolites in $\mathrm{D}_{2} \mathrm{O}$-media: amino acids, proteins and carbohydrates. It is noted that adaptation to $\mathrm{D}_{2} \mathrm{O}$ occurs easier on complex growth media than on the minimal growth media with full substrates at a gradual increasing of deuterium content in the growth media, as the sensitivity to $\mathrm{D}_{2} \mathrm{O}$ of different vital systems is different. As a rule, even highly deuterated growth media contain remaining protons $\sim 0,2-10$ atom. $\%$. These remaining protons facilitate the restructuring to the changed conditions during the adaptation to $\mathrm{D}_{2} \mathrm{O}$, presumably integrating into those sites, which are the most sensitive to the replacement of hydrogen by deuterium. The evidence has been obtained that cells evidently are able to regulate the $\mathrm{D} /{ }^{1} \mathrm{H}$ ratios, while its changes trigger distinct molecular processes. One possibility to modify intracellular $\mathrm{D} /{ }^{1} \mathrm{H}$ ratios is the activation of the $\mathrm{H}^{+}$transport system, which preferentially eliminates $\mathrm{H}^{+}$, resulting in increased $\mathrm{D} /{ }^{1} \mathrm{H}$ ratios within cells (Somlyai et al., 2012). Furthermore deuterium induces physiological, morphological and cytological alterations on the cell. There were marked the significant differences in the morphology of the protonated and deuterated cells of bluegreen algae $C$. vulgaris. Cells grown on $\mathrm{D}_{2} \mathrm{O}$-media were $\sim 2-3$ times larger in size and had thicker cell walls, than the control cells grown on a conventional protonated growth media with ordinary water, the distribution of DNA in them was non-uniform. In some cases on on the surface of cell membranes may be observed areas consisting of tightly packed pleats of a cytoplasmic membrane resembling mezosoms - intracytoplasmic bacterial membrane of vesicular structure and tubular form formed by the invasion of cytoplasmic membrane into the cytoplasm (Figure 1). It is assumed that mezosoms involved in the formation of cell walls, replication and segregation of DNA, nucleotides and other processes. There is also evidence that the majority number of mezosoms being absent in normal cells is formed by a chemical action of some external factors - low and high temperatures, fluctuation of $\mathrm{pH}$ and and other factors. Furthermore, deuterated cells of $C$. vulgaris were also characterized by a drastic change in cell form and direction of their division. The observed cell division cytodieresis did not end by the usual divergence of the daughter cells, but led to the formation of abnormal cells, as described by other authors (Eryomin et al., 1978). The observed morphological changes associated with the inhibition of growth of deuterated cells were stipulated by the cell restructuring during the process of adaptation to $\mathrm{D}_{2} \mathrm{O}$. The fact that the deuterated cells are larger in size (apparent size was of $\sim 2-4$ times larger than the size of the protonated cells), apparently is a general biological phenomenon proved by growing a number of other adapted to $\mathrm{D}_{2} \mathrm{O}$ prokaryotic and eukaryotic cells (Mosin \& Ignatov, 2013; Mosin \& Ignatov, 2014a; Mosin \& Ignatov, 2014b). 


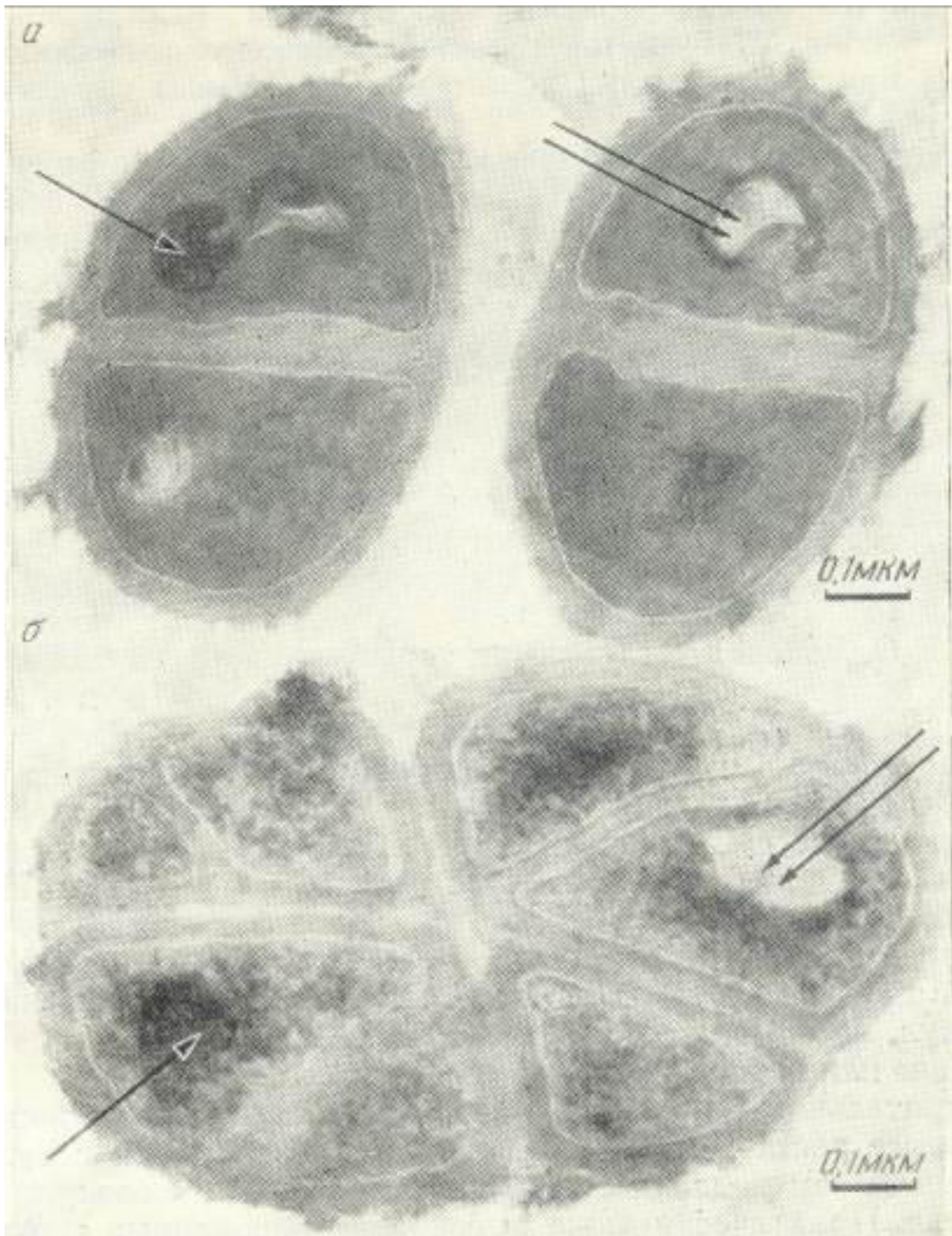

Figure 1: Electron micrographs of Micrococcus lysodeikticus cells obtained by SEM method: $a$ ) - protonated cells obtained on $\mathrm{H}_{2} \mathrm{O}$-medium; $b$ ) - deuterated cells obtained on $\mathrm{D}_{2} \mathrm{O}$-medium. The arrows indicate the tightly-packed portions of the membranes

Our data generally confirm a stable notion that adaptation to $\mathrm{D}_{2} \mathrm{O}$ is a phenotypic phenomenon as the adapted cells eventually return back to the normal growth after some lag-period after their replacement back onto $\mathrm{H}_{2} \mathrm{O}$-medium. However, the effect of reversion of growth on $\mathrm{H}_{2} \mathrm{O} / \mathrm{D}_{2} \mathrm{O}$ media does not exclude an opportunity that a certain genotype determines the manifestation of the same phenotypic attribute in $\mathrm{D}_{2} \mathrm{O}$-media with high deuterium content. At placing a cell onto $\mathrm{D}_{2} \mathrm{O}$-media lacking protons, not only $\mathrm{D}_{2} \mathrm{O}$ is removed from a cell due to isotopic $\left({ }^{1} \mathrm{H}-\mathrm{D}\right)$ exchange, but also there are occurred a rapid isotopic $\left({ }^{1} \mathrm{H}-\mathrm{D}\right)$ exchange in hydroxyl $(-\mathrm{OH})$, sulfohydryl (-SH) and amino $\left(-\mathrm{NH}_{2}\right)$ groups in all molecules of organic substances, including proteins, nucleic acids, carbohydrates and lipids. It is known, that in these conditions only covalent $\mathrm{C}-\mathrm{H}$ bond is not exposed to isotopic $\left({ }^{1} \mathrm{H}-\mathrm{D}\right)$ exchange and, thereof only molecules with bonds such as $\mathrm{C}-\mathrm{D}$ can be synthesized de novo (Mosin et al., 1996a; Mosin \& Ignatov, 2012a). Depending on the position of the deuterium atom in the molecule, there are distinguished primary and secondary isotopic effects mediated by intermolecular interactions. In this aspect, the most important for the structure of macromolecules are dynamic short-lived hydrogen (deuterium) bonds formed between the electron deficient ${ }^{1} \mathrm{H}(\mathrm{D})$ atoms and adjacent electronegative $\mathrm{O}$, C, N, S- heteroatoms in the molecules, acting as acceptors of H-bond (Ignatov \& Mosin, 2013c). The hydrogen bond, based on weak electrostatic forces, donor-acceptor interactions with charge-transfer and intermolecular van der Waals forces, is of the vital importance in the chemistry of intermolecular interactions and maintaining the spatial structure of macromolecules in aqueous solutions (Ignatov \& Mosin, 2013d). Another important property is defined by the three-dimensional structure of $\mathrm{D}_{2} \mathrm{O}$ molecule having the tendency to pull together hydrophobic groups of macromolecules to minimize their disruptive effect on the hydrogen (deuterium)-bonded network in $\mathrm{D}_{2} \mathrm{O}$. This leads to stabilization of the structure of protein and nucleic acid macromolecules in the presence of $\mathrm{D}_{2} \mathrm{O}$. That is why, the structure of macromolecules of proteins and nucleic acids in the presence of 
$\mathrm{D}_{2} \mathrm{O}$ are somehow stabilized (Cioni \& Strambini, 2002).

Evidently the cell implements special adaptive mechanisms promoting the functional reorganization of vital systems in ${ }^{2} \mathrm{H}_{2} \mathrm{O}$. Thus, for the normal synthesis and function in $\mathrm{D}_{2} \mathrm{O}$ of such vital compounds as nucleic acids and proteins contributes to the maintenance of their structure by forming hydrogen (deuterium) bonds in the molecules. The bonds formed by deuterium atoms are differed in strength and energy from similar bonds formed by hydrogen. Somewhat greater strength of D-O bond compared to D-O bond causes the differences in the kinetics of reactions in $\mathrm{H}_{2} \mathrm{O}$ and $\mathrm{D}_{2} \mathrm{O}$. Thus, according to the theory of a chemical bond the breaking up of covalent ${ }^{1} \mathrm{H}-\mathrm{C}$ bonds can occur faster than $\mathrm{C}-\mathrm{D}$ bonds, the mobility of $\mathrm{D}_{3} \mathrm{O}^{+}$ion is lower on $28.5 \%$ than $\mathrm{H}_{3} \mathrm{O}^{+}$ ion, and $\mathrm{OD}^{-}$ion is lower on $39.8 \%$ than $\mathrm{OH}^{-}$ion, the constant of ionization of $\mathrm{D}_{2} \mathrm{O}$ is less than that of $\mathrm{H}_{2} \mathrm{O}$ (Ignatov \& Mosin, 2013d). These chemical-physical factors lead to slowing down in the rates of enzymatic reactions in $\mathrm{D}_{2} \mathrm{O}$ (Cleland, 1976). However, there are also such reactions which rates in $\mathrm{D}_{2} \mathrm{O}$ are higher than in $\mathrm{H}_{2} \mathrm{O}$. In general these reactions are catalyzed by $\mathrm{D}_{3} \mathrm{O}^{+}$or $\mathrm{H}_{3} \mathrm{O}^{+}$ions or $\mathrm{OD}^{-}$and $\mathrm{OH}^{-}$ions. The substitution of ${ }^{1} \mathrm{H}$ with $\mathrm{D}$ affects the stability and geometry of hydrogen bonds in an apparently rather complex way and may, through the changes in the hydrogen bond zero-point vibration energies, alter the conformational dynamics of hydrogen (deuterium)-bonded structures of DNA and proteins in $\mathrm{D}_{2} \mathrm{O}$. It may cause disturbances in the DNAsynthesis during mitosis, leading to permanent changes on DNA structure and consequently on cell genotype (Lamprecht et al., 1989). Isotopic effects of deuterium, which would occur in macromolecules of even a small difference between hydrogen and deuterium, would certainly have the effect upon the structure. The sensitivity of enzyme function to the structure and the sensitivity of nucleic acid function (genetic and mitotic) would lead to a noticeable effect on the metabolic pathways and reproductive behavior of an organism in the presence of $\mathrm{D}_{2} \mathrm{O}$ (Török et al., 2010). And next, the changes in dissociation constants of DNA and protein ionizable groups when transferring the macromolecule from $\mathrm{H}_{2} \mathrm{O}$ into $\mathrm{D}_{2} \mathrm{O}$ may perturb the charge state of the DNA and protein molecules. All this can cause variations in nucleic acid synthesis, which can lead to structural changes and functional differences in the cell and its organelles. Hence, the structural and dynamic properties of the cell membrane, which depends on qualitative and quantitative composition of membrane's fatty acids, can also be modified in the presence of $\mathrm{D}_{2} \mathrm{O}$. The cellular membrane is one of the most important organelles in the bacteria for metabolic regulation, combining apparatus of biosynthesis of polysaccharides, transformation of energy, supplying cells with nutrients and involvement in the biosynthesis of proteins, nucleic acids and fatty acids. Obviously, the cell membrane plays an important role in the adaptation to $\mathrm{D}_{2} \mathrm{O}$. But it has been not clearly known what occurs with the membranes - how they react to the replacement of $\mathrm{H}^{+}$with $\mathrm{D}^{+}$and how it concerns the survival of cells in $\mathrm{D}_{2} \mathrm{O}$-media devoid of protons.

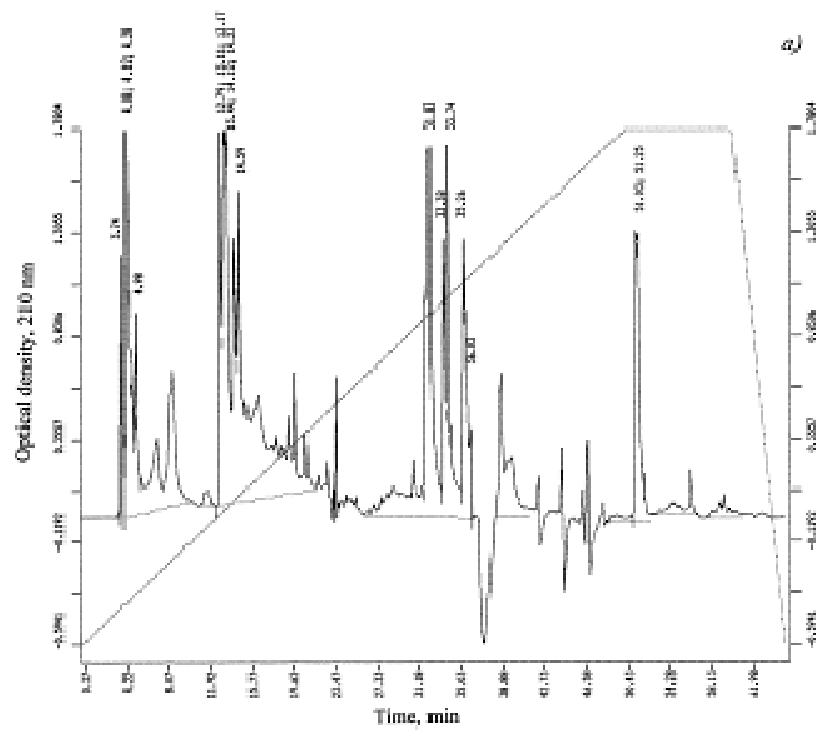




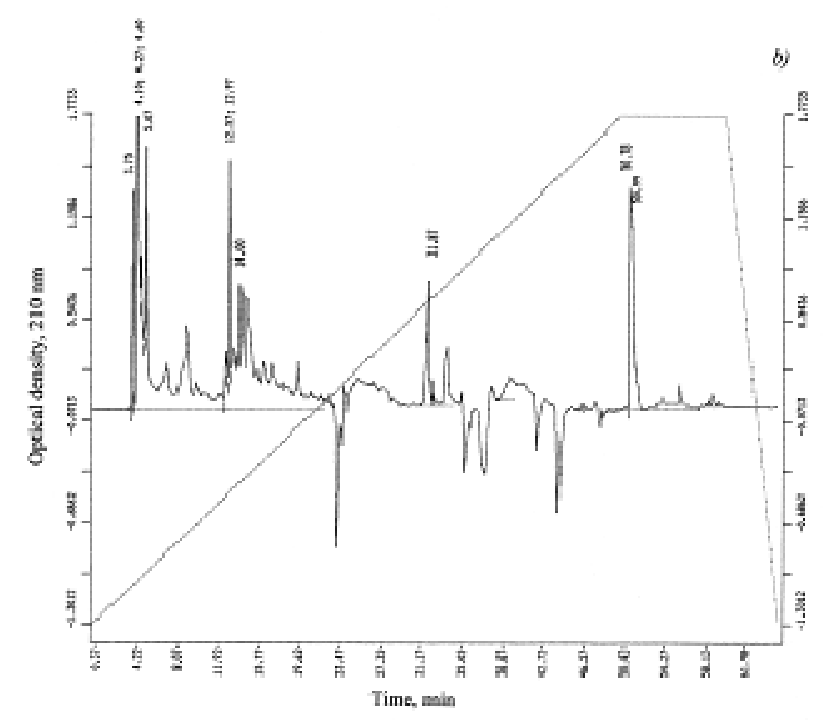

Figure 2: HPLC-chromatograms of fatty acids obtained from protonated $(a)$ and deuterated $(b)$ cells of B. subtilis on the maximally deuterated $\mathrm{D}_{2} \mathrm{O}$-medium: Beckman Gold System (Beckman, USA) chromatograph $(4.6 \times 250 \mathrm{~mm})$; stationary phase: Ultra sphere ODS, $5 \mu \mathrm{m}$; mobile phase: linear gradient $5 \mathrm{mM} \mathrm{KH}_{2} \mathrm{PO}_{4}-$ acetonitrile (shown in phantom), elution rate: $0.5 \mathrm{ml} / \mathrm{min}$, detection at $\lambda=210 \mathrm{~nm}$. The peaks with retention time $3.75 \mathrm{~min}$ (instead of 3.74 minutes in the control), 4.10; 4.27; 4.60 (instead of $4.08 ; 4.12 ; 4.28$ in the control), 5.07 (instead of 4.98 in control) $12.57 ; 12.97$ (instead of $12.79 ; 13.11 ; 13.17$ in control) 14.00 (instead of 14.59 in the control), 31.87 (instead of 31.83 in the control); 33.38; 33.74; 33.26; 36.03; 50.78; 50.99 (instead of 51.03; 51.25 for control) correspond to individual intracellular fatty acids

Comparative analysis of the fatty acid composition of deuterated cells of chemoheterotrophic bacteria B. subtilis, obtained on the maximum deuterated medium with 99.9 atom. $\% \mathrm{D}_{2} \mathrm{O}$ (Figure $2 \mathrm{~b}$ ), carried out by HPLC method, revealed significant quantitative differences in the fatty acid composition compared to the control obtained in ordinary water (Figure $2 \mathrm{a}$ ). Characteristically, in deuterated sample fatty acids having retention times at $33.38 ; 33.74 ; 33.26$ and 36.03 min are not detected in HPLC-chromatogram (Fig. 2b). This result is apparently due to the fact that the cell membrane is one of the first cell organelles, sensitive to the effects of $\mathrm{D}_{2} \mathrm{O}$, and thus compensates the changes in rheological properties of a membrane (viscosity, fluidity, structuredness) not only by quantitative but also by qualitative composition of membrane fatty acids. Similar situation was observed with the separation of other natural compounds (proteins, amino acids, carbohydrates) extracted from deutero-biomass obtained from maximally deuterated $\mathrm{D}_{2} \mathrm{O}$-medium.

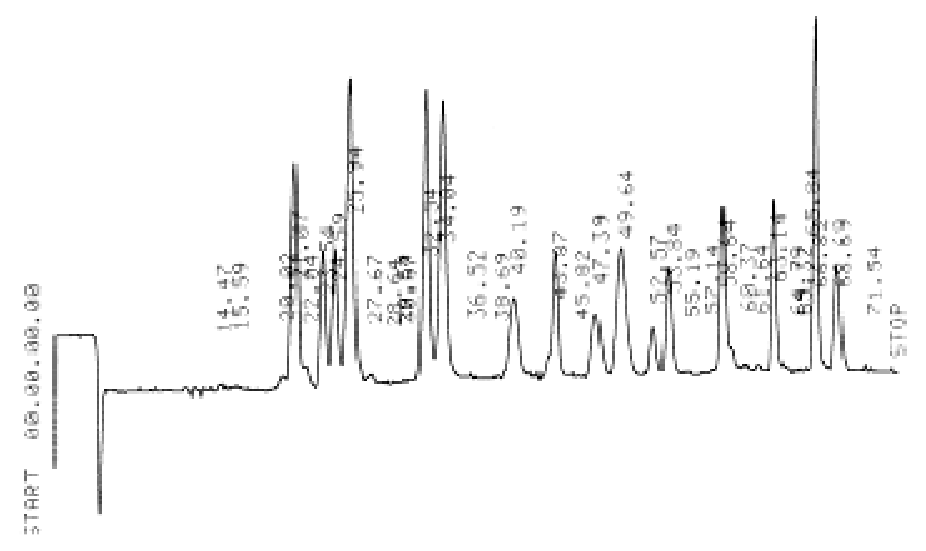




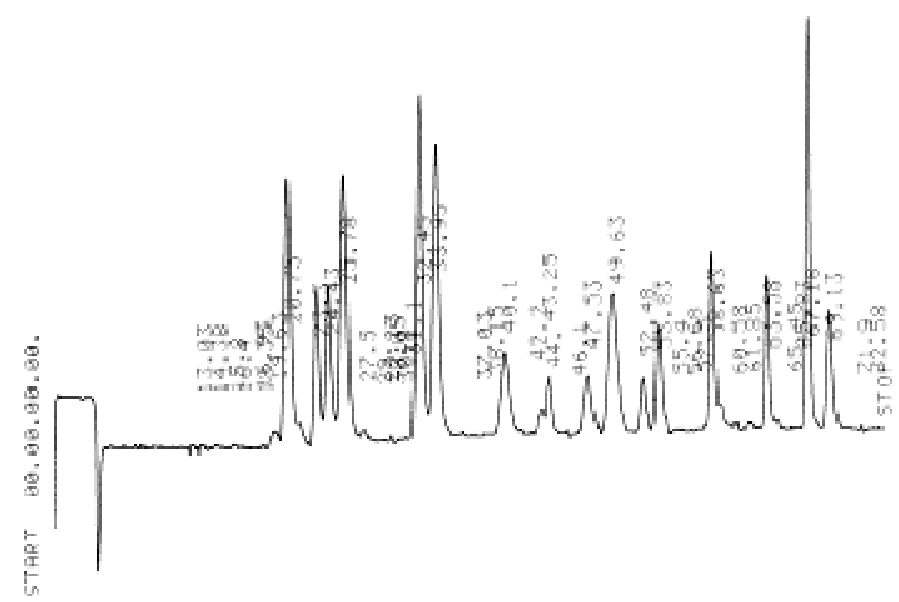

Figure 3: Ion-exchange chromatograms of amino acids obtained from hydrolyzates of protonated (a) and deuterated (b) cells of $B$. subtilis on the maximally deuterated $\mathrm{D}_{2} \mathrm{O}$-medium: Biotronic LC-5001 $(230 \times 3.2 \mathrm{~mm})$ column ("Eppendorf-Nethleler-Hinz", Germany); stationary phase: UR-30 sulfonated styrene resin ("Beckman-Spinco", USA); $25 \mu \mathrm{m}$; 50-60 atm; mobile phase: $0.2 \mathrm{~N}$ sodium-citrate buffer $(\mathrm{pH}=2.5)$; the eluent input rate: $18.5 \mathrm{ml} / \mathrm{h}$; the ninhydrin input rate: $9.25 \mathrm{ml} / \mathrm{h}$; detection at $\lambda=570$ and $\lambda=440 \mathrm{~nm}$ (for proline).

Table 1: Amino acid composition of the protein hydrolysates of B. subtilis, obtained on the maximum deuterated medium and levels of deuterium enrichment of molecules*

\begin{tabular}{|c|c|c|c|c|}
\hline \multirow[t]{2}{*}{ Amino acid } & \multicolumn{2}{|c|}{$\begin{array}{l}\text { Yield, } \%(w / w) \text { dry weight per } 1 \\
\text { gram of biomass }\end{array}$} & \multirow{2}{*}{$\begin{array}{l}\text { Number of deuterium } \\
\text { atoms incorporated into } \\
\text { the carbon backbone of a } \\
\text { molecule** }\end{array}$} & \multirow{2}{*}{$\begin{array}{l}\text { Level of deuterium enrichment } \\
\text { of molecules, } \% \text { of the total } \\
\text { number of hydrogen atoms } * * *\end{array}$} \\
\hline & $\begin{array}{l}\text { Protonated } \\
\text { sample } \\
\text { (control) }\end{array}$ & $\begin{array}{l}\text { The sample } \\
\text { obtained in } 99.9 \\
\text { atom.\% } \mathrm{D}_{2} \mathrm{O} \\
\end{array}$ & & \\
\hline Glycine & 8.03 & 9.69 & 2 & 90.0 \\
\hline Alanine & 12.95 & 13.98 & 4 & 97.5 \\
\hline Valine & 3.54 & 3.74 & 4 & 50.0 \\
\hline Leucine & 8.62 & 7.33 & 5 & 50.0 \\
\hline Isoleucine & 4.14 & 3.64 & 5 & 50.0 \\
\hline Phenylalanine & 3.88 & 3.94 & 8 & 95.0 \\
\hline Tyrosine & 1.56 & 1.83 & 7 & 92.8 \\
\hline Serine & 4.18 & 4.90 & 3 & 86.6 \\
\hline Threonine & 4.81 & 5.51 & - & - \\
\hline Methionine & 4.94 & 2.25 & - & - \\
\hline Asparagine & 7.88 & 9.59 & 2 & 66.6 \\
\hline Glutamic acid & 11.68 & 10.38 & 4 & 70.0 \\
\hline Lysine & 4.34 & 3.98 & 5 & 58.9 \\
\hline Arginine & 4.63 & 5.28 & - & - \\
\hline Histidine & 3.43 & 3.73 & - & - \\
\hline
\end{tabular}

Notes:

* The data obtained by mass spectrometry for the methyl esters of N-5-(dimethylamino) naphthalene-1-sulfonyl chloride (dansyl) amino acid derivatives.

** While calculating the level of deuterium enrichment protons (deuterons) at the carboxyl $(\mathrm{COOH}-)$ and $\mathrm{NH}_{2}-$ groups of amino acid molecules are not taken into account because of their easy dissociation in $\mathrm{H}_{2} \mathrm{O} / \mathrm{D}_{2} \mathrm{O}$ *** A dash means absence of data.

Amino acid analysis of protein hydrolysates isolated from deuterated cells of $B$. subtilis, also revealed the differences in quantitative composition of amino acids synthesized in $\mathrm{D}_{2} \mathrm{O}$-medium (Figure 3). Protein hydrolysate contains fifteen identified amino acids (except proline, which was detected at $\lambda=440 \mathrm{~nm}$ ) $($ Table 1 ). An indicator that determines a high efficiency of deuterium inclusion into amino acid molecules of protein hydrolyzates are high levels of deuterium enrichment of amino acid molecules, which are varied from 50 atom. $\%$ for leucine/isoleucine to 97.5 atom.\% for alanine. 
Qualitative and quantitative composition of the intracellular carbohydrates of B. subtilis obtained on maximally deuterated $\mathrm{D}_{2} \mathrm{O}$-medium is shown in Table 2 (the numbering is given to the sequence of their elution from the column) contained monosaccharides (glucose, fructose, rhamnose, arabinose), disaccharides (maltose, sucrose), and four other unidentified carbohydrates with retention time $3.08 \mathrm{~min}(15.63 \%) ; 4.26 \mathrm{~min}(7.46 \%)$; $7.23 \mathrm{~min}(11.72 \%)$ and $9.14 \mathrm{~min}(7.95 \%)$ (not shown) (Figure 4). Yield of glucose in deuterated sample makes up $21.4 \%$ by dry weight, i.e. higher than for fructose $(6.82 \%)$, rhamnose $(3.47 \%)$, arabinose $(3.69 \%)$, and maltose $(11.62 \%)$. Their outputs are not significantly different from the control in $\mathrm{H}_{2} \mathrm{O}$ except for sucrose in deuterated sample that was not detected (Table 2). The deuterium enrichment levels of carbohydrates were varied from 90.7 atom.\% for arabinose to 80.6 atom. $\%$ for glucose.

Table 2: Qualitative and quantitative composition of intracellular carbohydrates of $B$. subtilis obtained on the maximally deuterated medium and levels of deuterium enrichment of molecules*

\begin{tabular}{|c|c|c|c|}
\hline \multirow[t]{2}{*}{ Carbohydrate } & \multicolumn{2}{|c|}{$\begin{array}{l}\text { Content in the biomass, } \% \text { of the dry weight of } 1 \\
\mathrm{~g} \text { biomass }\end{array}$} & \multirow[t]{2}{*}{$\begin{array}{l}\text { Level of deuterium enrichment, } \% \text { of the } \\
\text { total number of hydrogen atoms } * * *\end{array}$} \\
\hline & $\begin{array}{l}\text { Protonated sample } \\
\text { (control) }\end{array}$ & $\begin{array}{l}\text { The sample obtained in } \\
99.9 \text { atom. } \% \mathrm{D}_{2} \mathrm{O} * *\end{array}$ & \\
\hline Glucose & 20.01 & 21.40 & 80.6 \\
\hline Fructose & 6.12 & 6.82 & 85.5 \\
\hline Rhamnose & 2.91 & 3.47 & 90.3 \\
\hline Arabinose & 3.26 & 3.69 & 90.7 \\
\hline Maltose & 15.30 & 11.62 & - \\
\hline Sucrose & 8.62 & ND & - \\
\hline
\end{tabular}

Notes:

* The data were obtained by IR-spectroscopy.

** ND - not detected

** A dash means the absence of data.

a)

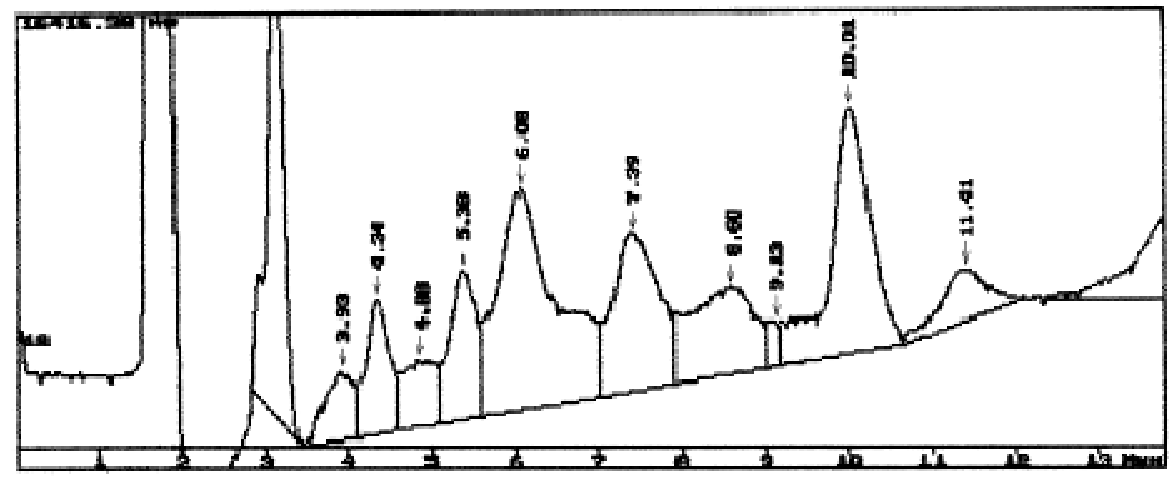

b)

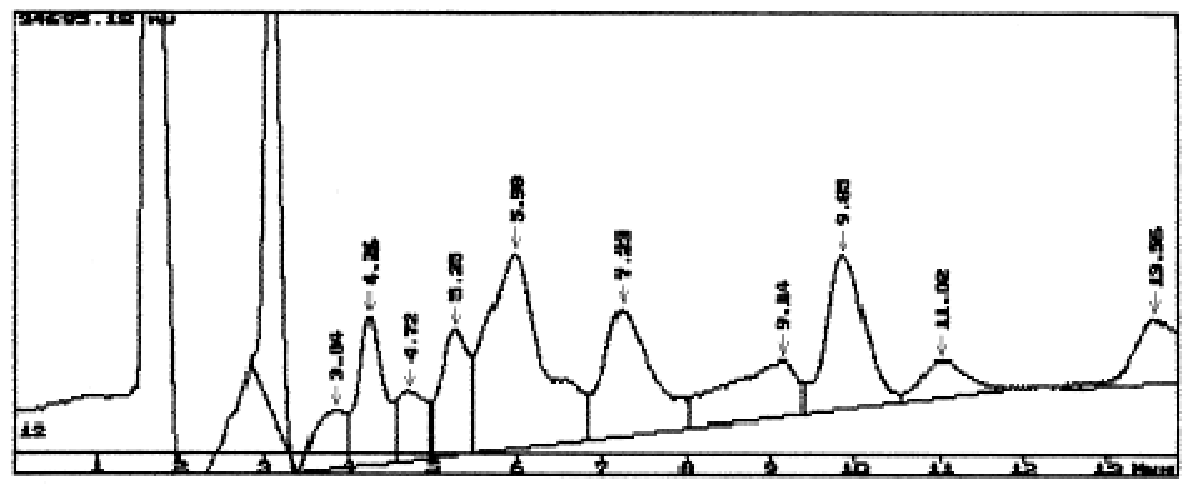

Figure 4: HPLC-chromatograms of intracellular carbohydrates obtained from protonated (a) and deuterated (b) cells of $B$. subtilis on the maximally deuterated $\mathrm{D}_{2} \mathrm{O}$-medium: Knauer Smartline chromatograph $(250 \times 10 \mathrm{~mm})($ "Knauer", 
Germany); stationary phase: Ultrasorb $\mathrm{CN} ; 10 \mu \mathrm{m}$; mobile phase: acetonitrile-water $(75: 25, \%$ (w/w); the input rate: $0.6 \mathrm{ml} / \mathrm{min}$

Electrophoregrams of proteins isolated from hydrolysates of total proteins of microbial biomass of $B$. subtilis grown on $\mathrm{D}_{2} \mathrm{O}$ also showed differences in the qualitative composition of total protein obtained on $\mathrm{D}_{2} \mathrm{O}$ (Figure 5).

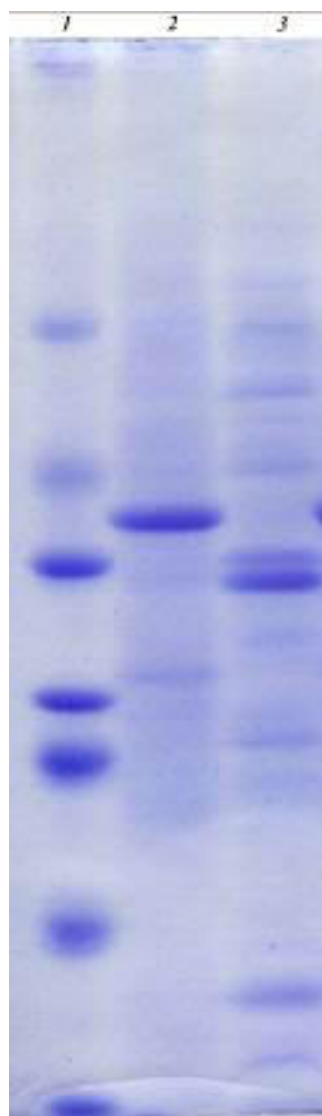

Figure 5: Electrophoregrams of proteins isolated from hydrolysates of total biomass of B. subtilis: 1 - a standard set of proteins; 2 - a sample obtained from protonated medium; 3 -- a sample obtained from $\mathrm{D}_{2} \mathrm{O}$-medium

The experimental data demonstrated that the effects observed at the cellular growth on $\mathrm{D}_{2} \mathrm{O}$-media possess a complex multifactor character stipulated by changes of morphological, cytological and physiological parameters - magnitude of the lag-period, time of cellular generation, outputs of biomass, a ratio of amino acids, protein, carbohydrates and fatty acids synthesized in $\mathrm{D}_{2} \mathrm{O}$, and with an evolutionary level of organization of investigated object as well. The cell evidently implements the special adaptive mechanisms promoting functional reorganization of work of the vital systems in the presence of $\mathrm{D}_{2} \mathrm{O}$. Thus, the most sensitive to replacement of ${ }^{1} \mathrm{H}$ on $\mathrm{D}$ are the apparatus of biosynthesis of macromolecules and a respiratory chain, i.e., those cellular systems using high mobility of protons and high speed of breaking up of hydrogen bonds. Last fact allows the consideration of adaptation to $\mathrm{D}_{2} \mathrm{O}$ as adaptation to the nonspecific factor affecting simultaneously the functional condition of several numbers of cellular systems: metabolism, ways of assimilation of carbon substrates, biosynthetic processes, and transport function, structure and functions of deuterated macromolecules. It seems to be reasonable to choose as biomodels in these studies microorganisms, as they are very well adapted to the environmental conditions and able to withstand high concentrations of $\mathrm{D}_{2} \mathrm{O}$ in growth media.

\subsection{The Research of Various Water Samples on the Feasibility for Origin of Life}

Further we carried out the research of various samples of mineral water obtained from mineral springs and seawater from Bulgaria (Fig. 6, curves 1-5). For this aim we employed the IR-spectrometry and DNES method relative to the control - deionized water.

For calculation of the function $f(E)$ represented the energy spectrum of water, the experimental dependence between the wetting angle $(\theta)$ and the energy of hydrogen bonds $(E)$ is established:

where $b=14,33 \mathrm{eV}^{-1}$

$$
f(E)=\frac{14,33 f(\theta)}{\left[1-(1+b E)^{2}\right]^{2}},
$$


The relation between the wetting angle $(\theta)$ and the energy $(E)$ of the hydrogen bonds between $\mathrm{H}_{2} \mathrm{O}$ molecules is calculated by the formula:

$$
\theta=\operatorname{arcos}(-1-14,33 E)
$$

Cactus juice was also investigated by the DNES method (Fig. 6, curve 1). The cactus was selected as a model system because this plant contains approximately $90 \%$ of water. The closest to the spectrum of cactus juice was the spectrum of mineral water contacting $\mathrm{Ca}^{2+}$ and $\mathrm{HCO}_{3}{ }^{-}$ions (Fig. 6, curve 2). DNES-spectra of cactus juice and mineral water have magnitudes of local maximums at $-0.1112 ;-0.1187 ;-0.1262 ;-0.1287$ and $0.1387 \mathrm{eV}$. Similar local maximums in the DNES-spectrum between cactus juice and seawater were detected at $0,1362 \mathrm{eV}$. The spectrum of the control sample of deionized water (Fig. 6, curve 5) was substantially different from the spectra of seawater and mineral water.

Another important parameter was measured by the DNES method - the average energy $\left(\Delta \mathrm{E}_{\mathrm{H} \ldots \mathrm{o}}\right)$ of hydrogen H...O-bonds among individual molecules $\mathrm{H}_{2} \mathrm{O}$, which makes up $-0,1067 \pm 0,0011 \mathrm{eV}$. When the water temperature is changed, the average energy of hydrogen H...O-bonds alternates. This testified about the restructuring of average energies among individual $\mathrm{H}_{2} \mathrm{O}$ molecules with a statistically reliable increase of local maximums in DNES-spectra.

Dr. Ignatov, Dr. Mosin, 2010

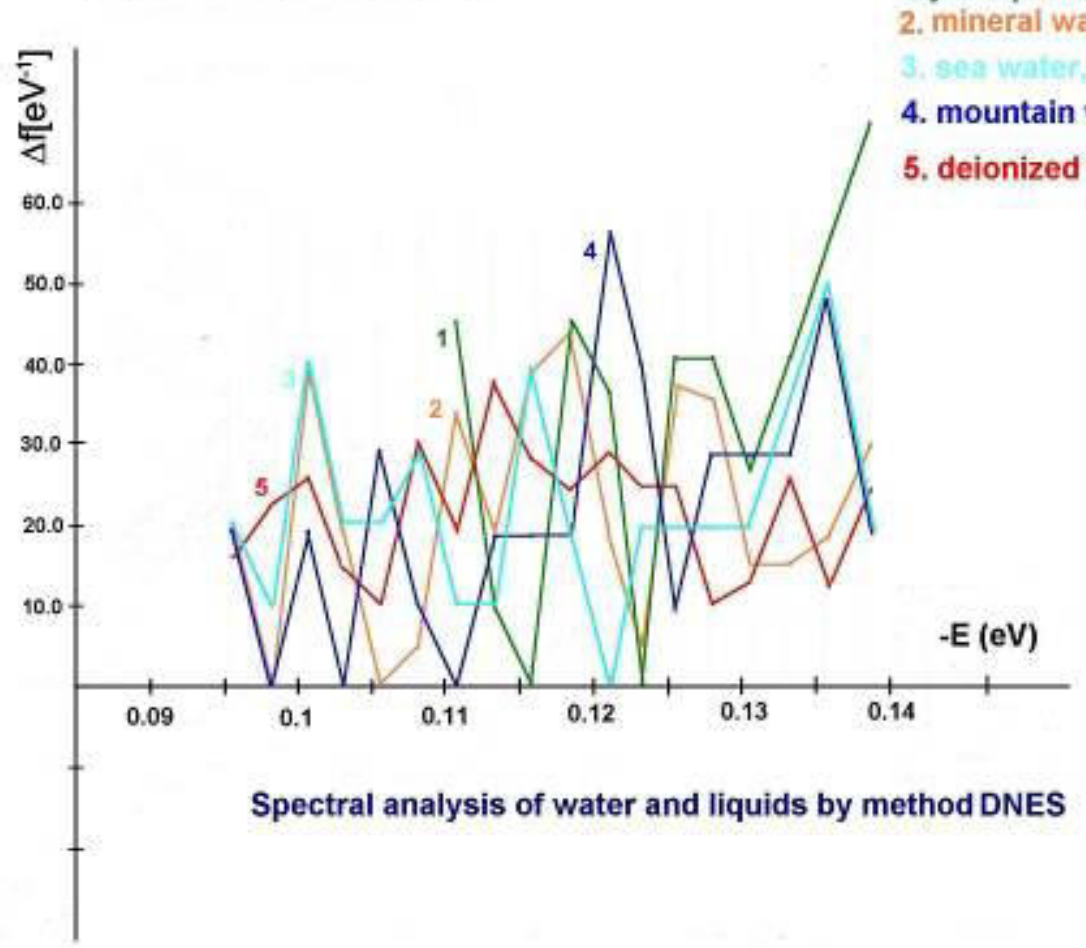

Figure 6: DNES-spectra of water samples of various origin: 1 - cactus juice; 2 - mineral water from Rupite village (Bulgaria); 3 - seawater (Varna, Bulgaria); 4 - mountain water (Teteven, Bulgaria); 5 - deionized water (the control)

As shown from these data, the closest to the IR-spectrum of cactus juice was mineral water from Rupite Village (Bulgaria), which DNES and IR spectrum is shown in Fig. 7 and Fig. 8 (Thermo Nicolet Avatar 360 Fourier-transform IR). IR-spectra of cactus juice and mineral water with $\mathrm{HCO}_{3}{ }^{-}(1320-1488 \mathrm{mg} / \mathrm{l}), \mathrm{Ca}^{2+}(29-$ $36 \mathrm{mg} / \mathrm{l}), \mathrm{pH}$ (6.85-7.19), have local maximums at $8.95 ; 9.67 ; 9.81 ; 10.47$ and $11.12 \mu \mathrm{m}$ (Fourier-IR spectrometer Brucker Vertex). Common local maximums in the IR-spectrum between cactus juice and seawater are detected at $9.10 \mu \mathrm{m}$. The local maximums obtained with IR method at $9.81 \mu \mathrm{m}\left(1019 \mathrm{~cm}^{-1}\right)$ and $8.95 \mu \mathrm{m}$ $\left(1117 \mathrm{~cm}^{-1}\right)$ (Thermo Nicolet Avatar 360 Fourier-transform IR) are located on the spectral curve of the local maximum at $9.7 \mu \mathrm{m}\left(1031 \mathrm{~cm}^{-1}\right)$ (Fig. 3). With the DNES method were obtained the following results - 8.95; 9.10; 9.64; 9.83; 10.45 and $11.15 \mu \mathrm{m}$, or $897 ; 957 ; 1017 ; 1037 ; 1099$ and 1117 wave numbers. 
Wavelength, $\mu \mathrm{m}$

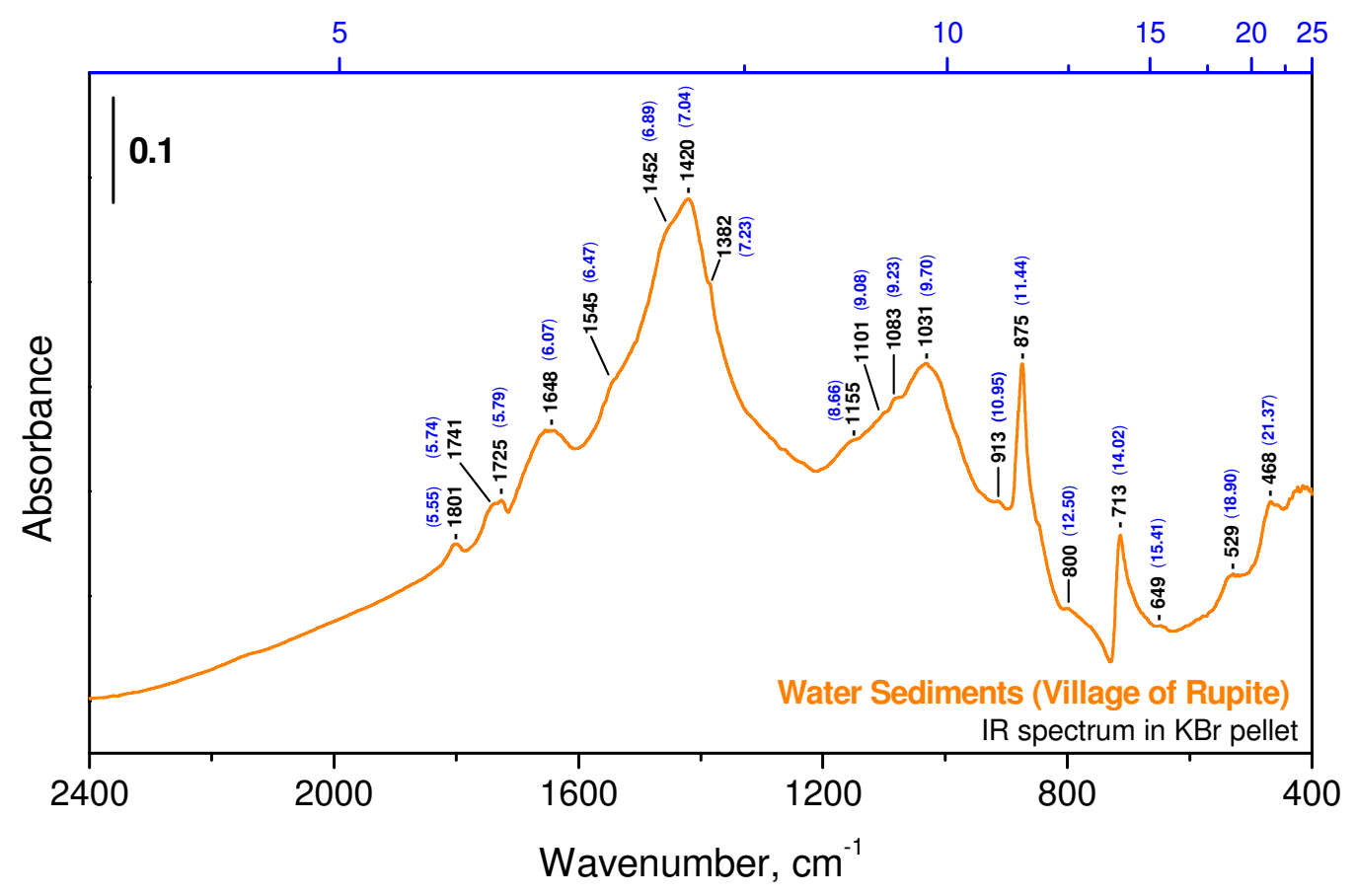

Figure 7: IR-spectrum of water obtained from Rupite Village (Bulgaria)

Table 3: Characteristics of spectra of water of various origin obtained by DNES-method*

\begin{tabular}{|c|c|c|c|c|}
\hline \multicolumn{3}{|c|}{$-\mathrm{E}, \mathrm{eV}$} & \multirow{2}{*}{$\begin{array}{c}\lambda, \\
\mu \mathrm{m}\end{array}$} & \multirow{2}{*}{$\begin{array}{c}\mathrm{k}, \\
\mathrm{cm}^{-1} \\
\end{array}$} \\
\hline Cactus juice & Mineral water from Rupite Village (Bulgaria) & Seawater & & \\
\hline 0.1112 & 0.1112 & - & 11.15 & 897 \\
\hline 0.1187 & 0.1187 & - & 10.45 & 957 \\
\hline 0.1262 & 0.1262 & - & 9.83 & 1017 \\
\hline 0.1287 & 0.1287 & - & 9.64 & 1037 \\
\hline 0.1362 & - & 0,1362 & 9.10 & 1099 \\
\hline 0.1387 & 0.1387 & - & 8.95 & 1117 \\
\hline
\end{tabular}

The note:

*The function of the distribution of energies $\Delta \mathrm{f}$ among individual $\mathrm{H}_{2} \mathrm{O}$ molecules was measured in reciprocal electron volts $\left(\mathrm{eV}^{-1}\right)$. It is shown at which values of the spectrum $-\mathrm{E}(\mathrm{eV})$ are observed the biggest local maximums of this function; $\lambda$ - wave length; $\kappa$ - wave number.

The results with Mediterranean jellyfish Cotylorhiza tuberculata indicated that jellyfish has local maximums in IR-spectra at 8.98 and $10.18 \mu \mathrm{m}$ (Fig. 8). Before measurements the jellyfish was kept in seawater for several days. On comparison seawater has a local maximum at $8.93 \mu \mathrm{m}$ in IR-spectra. These results were obtained with Thermo Nicolet Avatar 360 Fourier-transform IR. With DNES method the local maximums in spectra for jellyfish are at 8.95 and $10.21 \mu \mathrm{m}$, and for seawater at $9.10 \mu \mathrm{m}$. A differential spectrum was recorded between jellyfish and seawater by using the Thermo Nicolet Avatar 360 Fourier-transform IR method. In IRspectrum of jellyfish are observed more pronouncedly expressed local maximums, detected by Thermo Nicolet Avatar 360 Fourier-transform IR and DNES method. Measurements demonstrate that two common local maximums are observed in IR-spectra of jellyfish and seawater. These maximums are not observed in the IRspectrum of cactus juice and mineral water from Rupite (Bulgaria). Jellyfish contains approximately 97 (w/w) \% of water and is more unstable living organism compared to those ones formed stromatolites. The explanation for this is the smaller concentration of salts and, therefore, the smaller number of local maximums in the IRspectrum in relation to seawater. 


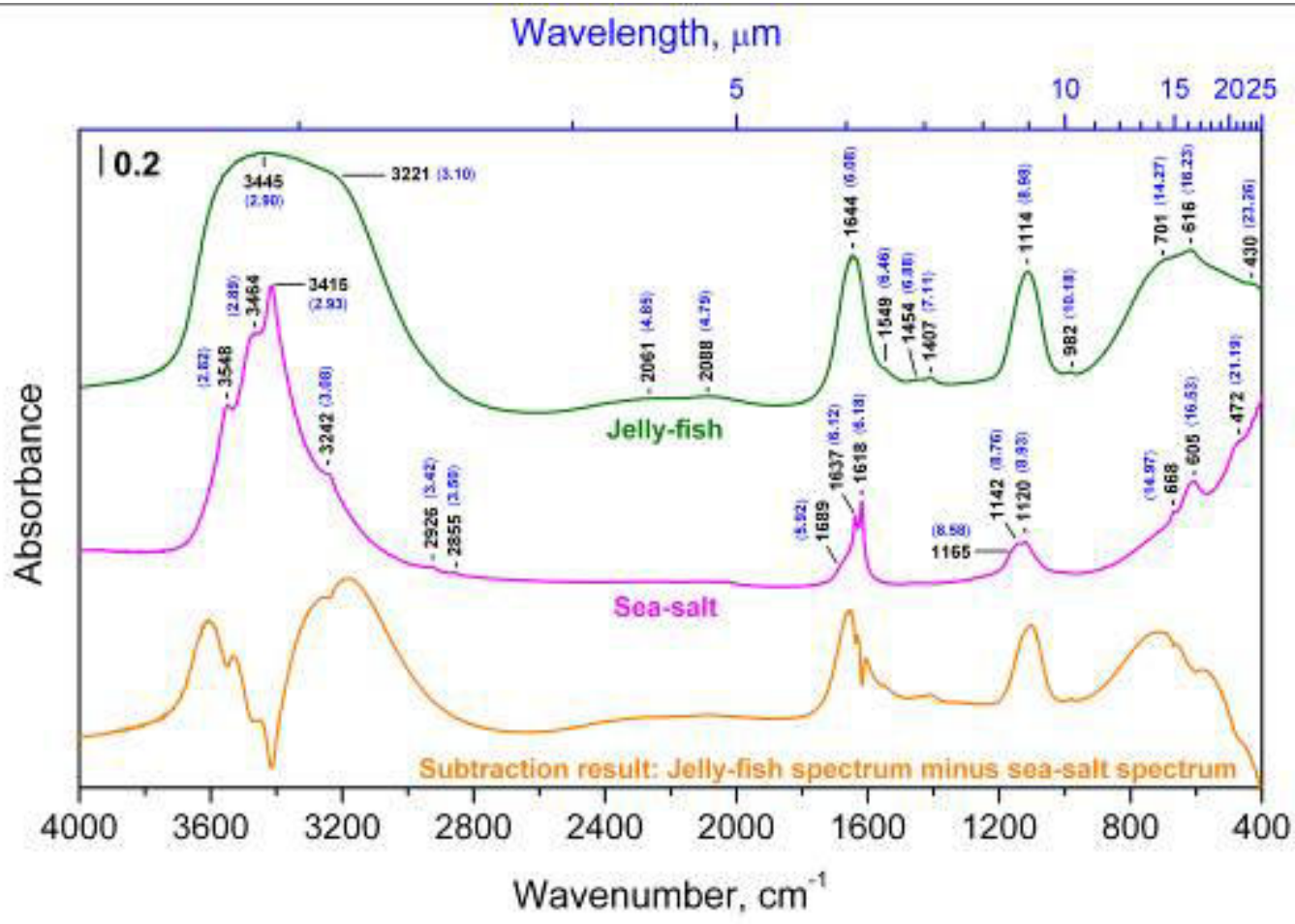

Figure 8: IR-spectrum of seawater obtained from Varna (Bulgaria) and jellyfish Cotylorhiza tuberculata,

Chalkida (Greece), Aegean Sea

Such a character of IR- and DNES-spectra and distribution of local maximums may prove that hot mineral alkaline water is preferable for origin and maintenance of life compared to other types of water analyzed by these methods. Thus, in hot mineral waters the local maximums in the IR-spectrum are more manifested compared to the local maximums obtained in IR-spectrum of the same water at a lower temperature. The difference in the local maximums from $+20{ }^{0} \mathrm{C}$ to $+95{ }^{\circ} \mathrm{C}$ at each $5{ }^{\circ} \mathrm{C}$ according to the Student t-criterion makes up $-\mathrm{p}<0.05$. These data indicate that the origination of life and living matter depends on the structure and physical chemical properties of water, as well as its temperature and $\mathrm{pH}$ value. The most closed to the IR- and DNES-spectrum of water, which contains bicarbonates and calcium ions typical for the formation of stromatolites is the IR-spectrum of cactus juice. For this reason cactus juice was applied as a model system. The most closed to local maximums in IR-spectrum of cactus juice are local maximums in IR-spectra of alkaline mineral water interacting with $\mathrm{CaCO}_{3}$ and then seawater. In connection with these data the following reactions participating with $\mathrm{CaCO}_{3}$ in aqueous solutions are important:

$$
\begin{aligned}
& \mathrm{CO}_{2}+4 \mathrm{H}_{2} \mathrm{~S}+\mathrm{O}_{2}=\mathrm{CH}_{2} \mathrm{O}+4 \mathrm{~S}+3 \mathrm{H}_{2} \mathrm{O} \\
& \mathrm{CaCO}_{3}+\mathrm{H}_{2} \mathrm{O}+\mathrm{CO}_{2}=\mathrm{Ca}\left(\mathrm{HCO}_{3}\right)_{2}, \\
& \mathrm{CO}_{2}+\mathrm{OH}^{-} \mathrm{HCO}_{3}^{-} \\
& 2 \mathrm{HCO}_{3}^{-}+\mathrm{Ca}^{2+}=\mathrm{CaCO}_{3}+\mathrm{CO}_{2}+\mathrm{H}_{2} \mathrm{O}
\end{aligned}
$$

The equation (3) shows how some chemosynthetic bacteria use energy from the oxidation of $\mathrm{H}_{2} \mathrm{~S}$ and $\mathrm{CO}_{2}$ to $\mathrm{S}$ and formaldehyde $\left(\mathrm{CH}_{2} \mathrm{O}\right)$. The equation (4) is related to one of the most common processes in nature: in the presence of $\mathrm{H}_{2} \mathrm{O}$ and $\mathrm{CO}_{2}, \mathrm{CaCO}_{3}$ transforms into $\mathrm{Ca}\left(\mathrm{HCO}_{3}\right)_{2}$. In the presence of hydroxyl $\mathrm{OH}^{-}$ions, $\mathrm{CO}_{2}$ transforms into $\mathrm{HCO}_{3}{ }^{-}$(equation (5). Equation (6) is valid for the process of formation of the stromatolites - the dolomite layered acretionary structures formed in shallow seawater by colonies of cyanobacteria. In $2010 \mathrm{D}$. Ward described fossilized stromatolites in the Glacier National Park (USA) (Schirber, 2010). Stromatolites aged 3.5 billion years had lived in warm and hot water in zones of volcanic activity, which could be heated by magma. This suggests that the first living forms evidently evolved in hot geysers (Ponsa et al., 2011). It is known that water in geysers is rich in carbonates, while the temperature is ranged from $+100{ }^{0} \mathrm{C}$ to $+150{ }^{0} \mathrm{C}$. In 2011 a team of Japanese scientists under the leadership of T. Sugawara showed that life originated in warm or, more likely, hot water (Kurihara et al., 2011). From aqueous solution of organic molecules, DNA and synthetic enzymes were created proto cells. For this the initial solution was heated to a temperature close to water's boiling point $+95{ }^{0} \mathrm{C}$. Then its temperature was lowered to $+65{ }^{\circ} \mathrm{C}$ with formation of proto cells with primitive membrane. This laboratory experiment is an excellent confirmation of the possibility that life originated in hot water. 


\subsection{IR-Spectroscopy of Water with Varying Content of Deuterium}

The comparative analysis of IR-spectra of $\mathrm{H}_{2} \mathrm{O}$ solutions and its deuterated analogues $\left(\mathrm{D}_{2} \mathrm{O}, \mathrm{HDO}\right)$ is of considerable interest for biophysical studies, because at changing of the atomic mass of hydrogen by deuterium atoms in $\mathrm{H}_{2} \mathrm{O}$ molecule their interaction will also change, although the electronic structure of the molecule and its ability to form $\mathrm{H}$-bonds, however, remains the same. The IR spectra of water usually contain three absorption bands, which can be identified as 1 - absorption band of the stretching vibration of $\mathrm{OH}^{-}$group; 2 - absorption band of the first overtone of the bending vibration of the molecule HDO; 3 - absorption band of stretching vibration of $\mathrm{OD}^{-}$group. $\mathrm{OH}^{-}$group is able to absorb much infrared radiation in the infrared region of the IRspectrum. Because of its polarity, these groups typically react with each other or with other polar groups to form intra-and intermolecular hydrogen bonds. The hydroxyl groups not involved in formation of hydrogen bonds are usually given the narrow bands in IR spectrum and the associated groups - broad intense absorption bands at lower frequencies. The magnitude of the frequency shift is determined by the strength of the hydrogen bond. Complication of the IR spectrum in the area of $\mathrm{OH}^{-}$stretching vibrations can be explained by the existence of different types of associations, a manifestation of overtones and combination frequencies of $\mathrm{OH}^{-}$groups in hydrogen bonding, as well as the proton tunneling effect (on the relay mechanism. Such complexity makes it difficult to interpret the IR spectrum and partly explains the discrepancy in the literature available on this subject. The local maximums in IR-spectra reflect vibrational-rotational transitions in the ground electronic state; the substitution with deuterium changes the vibrational-rotational transitions in $\mathrm{H}_{2} \mathrm{O}$ molecule, that is why it appear other local maximums in IR-spectra. In the water vapor state, the vibrations involve combinations of symmetric stretch $\left(v_{1}\right)$, asymmetric stretch $\left(v_{3}\right)$ and bending $\left(v_{2}\right)$ of the covalent bonds with absorption intensity $\left(\mathrm{H}_{2} \mathrm{O}\right)$ $v_{1} ; v_{2} ; v_{3}=2671 ; 1178.4 ; 2787.7 \mathrm{~cm}^{-1}$. For liquid water absorption bands are observed in other regions of the IRspectrum, the most intense of which are located at $2100, \mathrm{~cm}^{-1}$ and $710-645 \mathrm{~cm}^{-1}$. For $\mathrm{D}_{2} \mathrm{O}$ molecule these ratio compiles 2723.7, 1403.5 and $3707.5 \mathrm{~cm}^{-1}$, while for HDO molecule - 2671.6, 1178.4 and $2787.7 \mathrm{~cm}^{-1}$. HDO (50 mole $\% \mathrm{H}_{2} \mathrm{O}+50$ mole $\%{ }^{2} \mathrm{H}_{2} \mathrm{O} ; \sim 50 \% \mathrm{HDO}, \sim 25 \% \mathrm{H}_{2} \mathrm{O}, \sim 25 \% \mathrm{D}_{2} \mathrm{O}$ ) has local maxima in IR-spectra at 3415 $\mathrm{cm}^{-1}, 2495 \mathrm{~cm}^{-1} 1850 \mathrm{~cm}^{-1}$ and $1450 \mathrm{~cm}^{-1}$ assigned to $\mathrm{OH}^{-}$-stretch, $\mathrm{OD}^{-}$-stretch, as well as combination of bending and libration and HDO bending respectively.

In the IR-spectrum of liquid water absorbance band considerably broadened and shifted relative to the corresponding bands in the spectrum of water vapor. Their position depends on the temperature (Ignatov \& Mosin, 2013b). The temperature dependence of individual spectral bands of liquid water is very complex (Zelsmann, 1995). Furthermore, the complexity of the IR-spectrum in the area of $\mathrm{OH}^{-}$stretching vibration can be explained by the existence of different types of $\mathrm{H}_{2} \mathrm{O}$ associations, manifestation of overtones and composite frequencies of $\mathrm{OH}^{-}$groups in the hydrogen bonds, and the tunneling effect of the proton (for relay mechanism) (Yukhnevitch, 1973). Such complexity makes it difficult to interpret the spectrum and partly explains the discrepancy in the literature available on this subject.

In liquid water and ice the IR-spectra are far more complex than those ones of the vapor due to vibrational overtones and combinations with librations (restricted rotations, e.g. rocking motions). These librations are due to the restrictions imposed by hydrogen bonding (minor $\mathrm{L}_{1}$ band at $395.5 \mathrm{~cm}^{-1}$; major $\mathrm{L}_{2}$ band at $686.3 \mathrm{~cm}^{-1}$; for liquid water at $0{ }^{0} \mathrm{C}$, the absorbance of $\mathrm{L}_{1}$ increasing with increasing temperature, while $\mathrm{L}_{2}$ absorbance decreases but broadens with reduced wave number with increasing temperature (Brubach et al., 2005). The IR spectra of liquid water usually contain three absorbance bands, which can be identified on absorption band of the stretching vibration of $\mathrm{OH}^{-}$group; absorption band of the first overtone of the bending vibration of the molecule HDO and absorption band of stretching vibration of $\mathrm{OD}^{-}$group (Max \& Chapados, 2009). Hydroxyl group $\mathrm{OH}^{-}$is able to absorb much infrared radiation in the infrared region of the IR-spectrum. Because of its polarity, these groups typically react with each other or with other polar groups to form intra-and intermolecular hydrogen bonds. The hydroxyl groups, which are not involved in formation of hydrogen bonds, usually produce the narrow bands in IR spectrum, while the associated groups - broad intense absorbance bands at lower frequencies. The magnitude of the frequency shift is determined by the strength of the hydrogen bond. Complication of the IR spectrum in the area of $\mathrm{OH}^{-}$stretching vibrations can be explained by the existence of different types of associations of $\mathrm{H}_{2} \mathrm{O}$ molecules, a manifestation of overtones and combination frequencies of $\mathrm{OH}^{-}$groups in hydrogen bonding, as well as the proton tunneling effect (on the relay mechanism).

Assignment of main absorbtion bands in the IR-spectrum of liquid water is given in Table 4. The IR spectrum of $\mathrm{H}_{2} \mathrm{O}$ molecule was examined in detail from the microwave till the middle $\left(4-17500 \mathrm{~cm}^{-1}\right)$ visible region and the ultraviolet region - from $200 \mathrm{~nm}^{-1}$ to ionization limit at $98 \mathrm{~nm}^{-1}$ (Walrafen, 1972). In the middle visible region at 4-7500 $\mathrm{cm}^{-1}$ are located rotational spectrum and the bands corresponding to the vibrationalrotational transitions in the ground electronic state. In the ultraviolet region (200 to $98 \mathrm{~nm}^{-1}$ ) are located bands corresponding to transitions from the excited electronic states close to the ionization limit in the electronic ground state. The intermediate region of the IR-spectrum - from $570 \mathrm{~nm}$ to $200 \mathrm{~nm}$ corresponds to transitions to higher vibrational levels of the ground electronic state. 
Table 4: The assignment of main frequencies in IR-spectra of liquid water $\mathrm{H}_{2} \mathrm{O}$ and $\mathrm{D}_{2} \mathrm{O}$

\begin{tabular}{|l|c|c|c|c|}
\hline \multicolumn{3}{|c|}{ Main vibrations of liquid $\mathrm{H}_{2} \mathrm{O}$ and ${ }^{2} \mathrm{H}_{2} \mathrm{O}$} \\
\hline Vibration(s) & \multicolumn{2}{|c|}{$\mathrm{H}_{2} \mathrm{O}\left(\mathrm{t}=25^{0} \mathrm{C}\right)$} & \multicolumn{2}{c|}{$\mathrm{D}_{2} \mathrm{O}\left(\mathrm{t}=25^{0} \mathrm{C}\right)$} \\
\cline { 2 - 5 } & $v, \mathrm{~cm}^{-1}$ & $\mathrm{E}_{0}, \mathrm{M}^{-1} \mathrm{~cm}^{-1}$ & $v, \mathrm{~cm}^{-1}$ & $\mathrm{E}_{0}, \mathrm{M}^{-1} \mathrm{~cm}^{-1}$ \\
\hline Spinning $v_{1}+$ deformation $v_{2}$ & $780-1645$ & 21.65 & 1210 & 17.10 \\
\hline Composite $v_{1}+v_{2}$ & 2150 & 3.46 & 1555 & 1.88 \\
\hline Valence symmetrical $v_{1}$, valence asymmetrical $v_{3}$, and overtone $2 v_{2}$ & $3290-3450$ & 100.65 & 2510 & 69.70 \\
\hline
\end{tabular}

Results of IR-spectroscopy with device Infra Spec VFA-IR show that at $4.1 \mu \mathrm{m}$, even at low concentrations of deuterium of 0.35 and $0.71 \%$, there is observed a decline in the local maximums relative to the local maximum of $100 \%$ pure water (the local maximums in IR-spectra reflect vibrational-rotational transitions in the ground electronic state because at changing the atomic mass of hydrogen and deuterium atoms in the water molecule their interaction will also change, although the electronic structure of the molecule and its ability to form $\mathrm{H}$ bonds, however, remains the same; with the substitution with deuterium the vibrational-rotational transitions are changed, that is why it appears other local maximums in IR-spectra. These results are shown in Figure 9. The result is reliable regarding the content of deuterium in natural waters from $0.015-0.03 \%$.

\section{ANALYGIS}

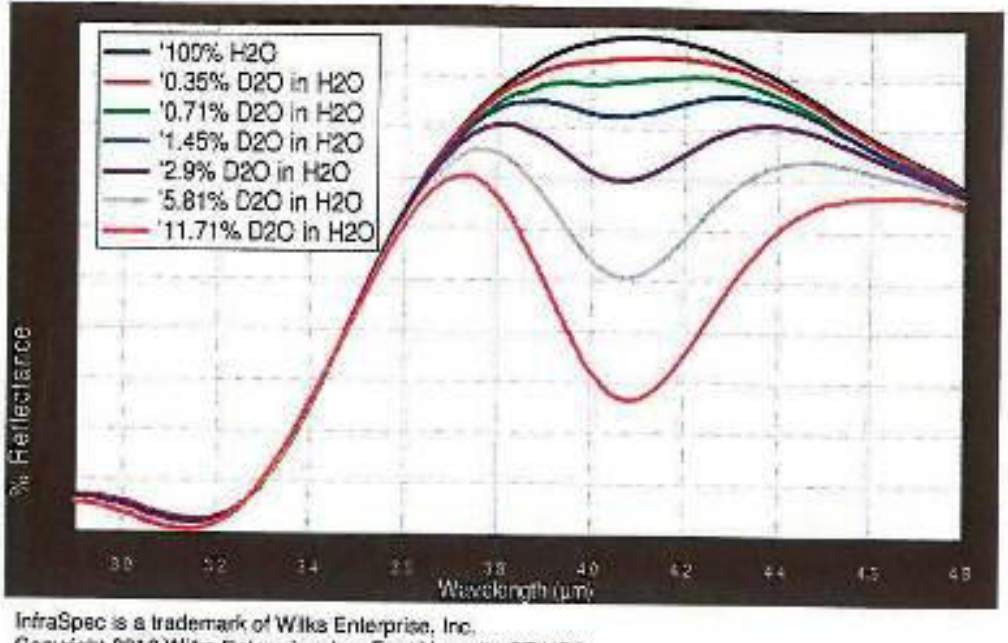

Copyright 2010 Wiks Entemprisa, Inc. East Norwalk, CT USA

Figure 9: The typical IR-spectra of water with varying content of deuterium

At further transition from $\mathrm{H}_{2} \mathrm{O}$ monomers to $\mathrm{H}_{4} \mathrm{O}_{2}$ dimmer and $\mathrm{H}_{6} \mathrm{O}_{3}$ trimmer absorption maximum of valent stretching vibrations of the $\mathrm{O}-\mathrm{H}$ bond is shifted toward lower frequencies $\left(\boldsymbol{v}_{3}=3490 \mathrm{~cm}^{-1}\right.$ and $\boldsymbol{v}_{1}=3280$ $\mathrm{cm}^{-1}$ ) (Eisenberg \& Kauzmann, 1969) and the bending frequency increased $\left(\boldsymbol{v}_{2}=1644 \mathrm{~cm}^{-1}\right)$ because of hydrogen bonding. The increased strength of hydrogen bonding typically shifts the stretch vibration to lower frequencies (red-shift) with greatly increased intensity in the infrared due to the increased dipoles. In contrast, for the deformation vibrations of the $\mathrm{H}-\mathrm{O}-\mathrm{H}$, it is observed a shift towards higher frequencies. Absorption bands at 3546 and $3691 \mathrm{~cm}^{-1}$ were attributed to the stretching modes of the dimmer $\left[\left(\mathrm{H}_{2} \mathrm{O}\right)_{2}\right]$. These frequencies are significantly lower than the valence modes of $v_{1}$ and $v_{3}$ vibrations of isolated $\mathrm{H}_{2} \mathrm{O}$ molecules at 3657 and 3756 $\mathrm{cm}^{-1}$ respectively). The absorbtion band at $3250 \mathrm{~cm}^{-1}$ represents overtones of deformation vibrations. Among frequencies between 3250 and $3420 \mathrm{~cm}^{-1}$ is possible Fermi resonance (this resonance is a single substitution of intensity of one fluctuation by another fluctuation when they accidentally overlap each other). The absorption band at $1620 \mathrm{~cm}^{-1}$ is attributed to the deformation mode of the dimmer. This frequency is slightly higher than the deformation mode of the isolated $\mathrm{H}_{2} \mathrm{O}$ molecule $\left(1596 \mathrm{~cm}^{-1}\right)$. A shift of the band of deformation vibration of water in the direction of high frequencies at the transition from a liquid to a solid state is attributed by the appearance of additional force, preventing O-H bond bending. Deformation absorption band in IR-spectrum of water has a frequency at $1645 \mathrm{~cm}^{-1}$ and very weak temperature dependence. It changes little in the transition to the individual $\mathrm{H}_{2} \mathrm{O}$ molecule at a frequency of $1595 \mathrm{~cm}^{-1}$. This frequency is found to be sufficiently stable, while all other frequencies are greatly affected by temperature changes, the dissolution of the salts and phase transitions. It is believed that the persistence of deformation oscillations is stipulated by processes of intermolecular interactions, e.g. by the change in bond angle as a result of interaction of $\mathrm{H}_{2} \mathrm{O}$ molecules with each other, as well as with cations and anions.

Thus the study of the characteristics of the IR spectrum of water allows to answer the question not only on the physical parameters of the molecule and the covalent bonds at isotopic substitution with deuterium, but also to make a certain conclusion on associative environment in water. The latter fact is important in the study of 
structural and functional properties of water associates and its isotopomers at the isotopic substitution with deuterium. The substitution of $\mathrm{H}$ with $\mathrm{D}$ affects the stability and geometry of hydrogen bonds in an apparently rather complex way and may, through the changes in the hydrogen bond zero-point vibration energies, alter the conformational dynamics of hydrogen (deuterium)-bonded structures of macromolecules as DNA and proteins in $\mathrm{D}_{2} \mathrm{O}$ (Cleland, 1976).

\subsection{The Reactions of Condensation-Dehydration in Hot Water}

The prognosis was made to predict a possible transition from synthesis of small organic molecules under high temperatures to more complex organic molecules as proteins. There are reactions of condensation-dehydration of amino acids into separate blocks of peptides that occur under alkaline conditions, with $\mathrm{pH}=9-11$. The important factor in reaction of condensation of two amino acid molecules into the dipeptide is allocation of $\mathrm{H}_{2} \mathrm{O}$ molecule when a peptide chain is formed, as the reaction of polycondensation of amino acids is accompanied by dehydration, the $\mathrm{H}_{2} \mathrm{O}$ removal from reaction mixture speeds up the reaction rates. This testifies that formation of early organic forms may have occured nearby active volcanoes, because at early periods of geological history volcanic activity occurred more actively than during subsequent geological times. However, dehydratation accompanies not only amino acid polymerization, but also association of other small blocks into larger organic molecules, and also polymerization of nucleotides into nucleic acids. Such association is connected with the reaction of condensation, at which from one block a proton is removed, and from another - a hydroxyl group with the formation of $\mathrm{H}_{2} \mathrm{O}$ molecule.

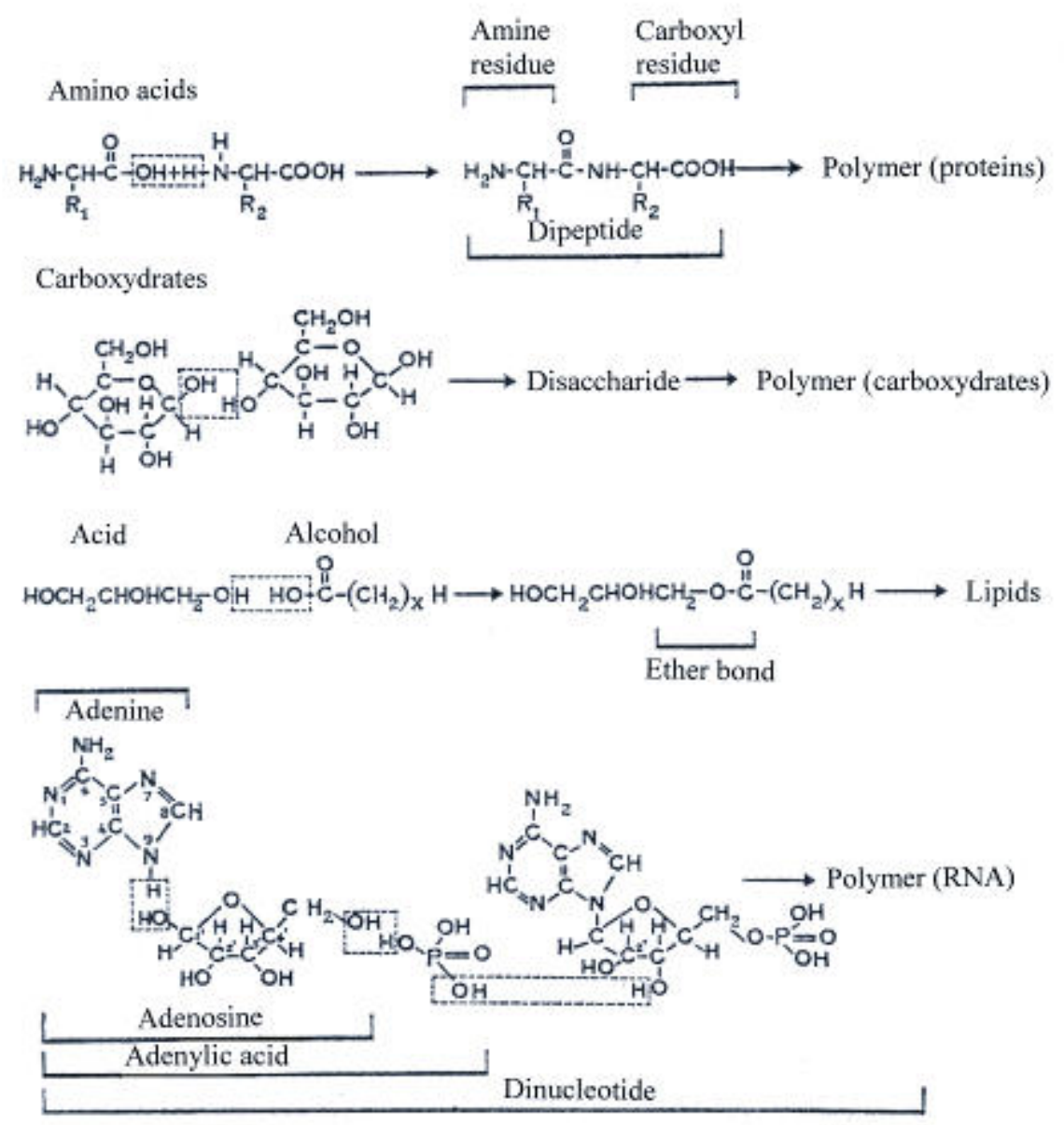

Figure 10: Reactions of condensation and dehydration in alkaline conditions with $\mathrm{pH}=9-10$ catalyzed by $\mathrm{HCN}$ and its derivatives, resulting in synthesis from separate molecules larger organic molecules of polymers. The top three equations: condensation and the subsequent polymerization of amino acids in proteins; carbohydrates - in polycarboxydrates and acids and ethers - into lipids. The bottom equation - condensation of adenine with ribose and $\mathrm{H}_{3} \mathrm{PO}_{4}$, leading to formation of dinucleotide

In 1969 the possibility of existence of condensation-dehydration reactions under conditions of primary hydrosphere was proven by M. Calvin (Calvin, 1969). From most chemical substances hydrocyanic acid (HCN) 
and its derivatives - cyanoamid $\left(\mathrm{CH}_{2} \mathrm{~N}_{2}\right)$ and dicyanoamid $\left(\mathrm{HN}(\mathrm{CN})_{2}\right)$ possess dehydration ability and the ability to catalyze the process of linkage of $\mathrm{H}_{2} \mathrm{O}$ from primary hydrosphere (Mathews \& Moser, 1968). The presence of $\mathrm{HCN}$ in primary hydrosphere was proven by S. Miller's early experiments (Miller, 1953). Chemical reactions with $\mathrm{HCN}$ and its derivatives are complex with a chemical point of view; in the presence of $\mathrm{HCN}, \mathrm{CH}_{2} \mathrm{~N}_{2}$ and $\mathrm{HN}(\mathrm{CN})_{2}$ the condensation of separate blocks of amino acids accompanied by dehydration, can proceed at normal temperatures in strongly diluted $\mathrm{H}_{2} \mathrm{O}$-solutions. These reactions show the results of synthesis from separate smaller molecules to larger organic molecules of polymers, e.g. proteins, polycarboxydrates, lipids, and nucleic asids (Fig. 10). Furthermore, polycondensation reactions catalyzed by HCN and its derivatives depend on acidity of water solutions in which they proceed (Abelson, 1966). In acid aqueous solutions with $\mathrm{pH}=4-6$ these reactions do not occur, whereas alkaline conditions with $\mathrm{pH}=9-10$ promote their course. There has not been unequivocal opinion, whether primary water was alkaline, but it is probable that such $\mathrm{pH}$ value possessed mineral waters adjoining with basalts, i.e. these reactions could occur at the contact of water with basalt rocks, that testifies our hypothesis.

It should be noted, that geothermal sources might be used for synthesis of various organic molecules. Thus, amino acids were detected in solutions of formaldehyde $\mathrm{CH}_{2} \mathrm{O}$ with hydroxylamine $\mathrm{NH}_{2} \mathrm{OH}$, formaldehyde with hydrazine $\left(\mathrm{N}_{2} \mathrm{H}_{4}\right)$ in water solutions with $\mathrm{HCN}$, after heating of a reactionary mixture to +95 ${ }^{0} \mathrm{C}$ (Harada \& Fox, 1964). In model experiments reaction products were polymerized into peptide chains that is the important stage towards inorganic synthesis of protein. In a reactionary mixture with a $\mathrm{HCN}-\mathrm{NH}_{3}$ solution in water were formed purines and pyrimidines (Fig. 11). In other experiments amino acid mixtures were subjected to influence of temperatures from $+60{ }^{0} \mathrm{C}$ up to $+170{ }^{0} \mathrm{C}$ with formation of short protein-like molecules resembling early evolutionary forms of proteins subsequently designated as thermal proteinoids. They consisted of 18 amino acids usually occurring in protein hydrolyzates. The synthesized proteinoids are similar to natural proteins on a number of other important properties, e. g. on linkage by nucleobases and ability to cause the reactions similar to those catalyzed by enzymes in living organisms as decarboxylation, amination, deamination, and oxidoreduction. Proteinoids are capable to catalytically decompose glucose (Fox \& Krampitz, 1964) and to have an effect similar to the action of $\alpha$-melanocyte-stimulating hormone (Fox \& Wang, 1968). The best results on polycondensation were achieved with the mixes of amino acids containing aspartic and glutamic acids, which are essential amino acids occurring in all modern living organisms.<smiles>N=C(N)c1nc[nH]c1N</smiles><smiles>Nc1ncnc2[nH]cnc12</smiles>

Adenine<smiles>NC(=O)c1nc[nH]c1N</smiles><smiles>Nc1nc(O)c2nc[nH]c2n1</smiles>

Guanine<smiles></smiles>

Hypoxanthine

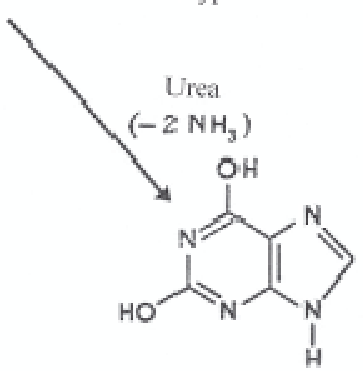

Xanthine

a) 


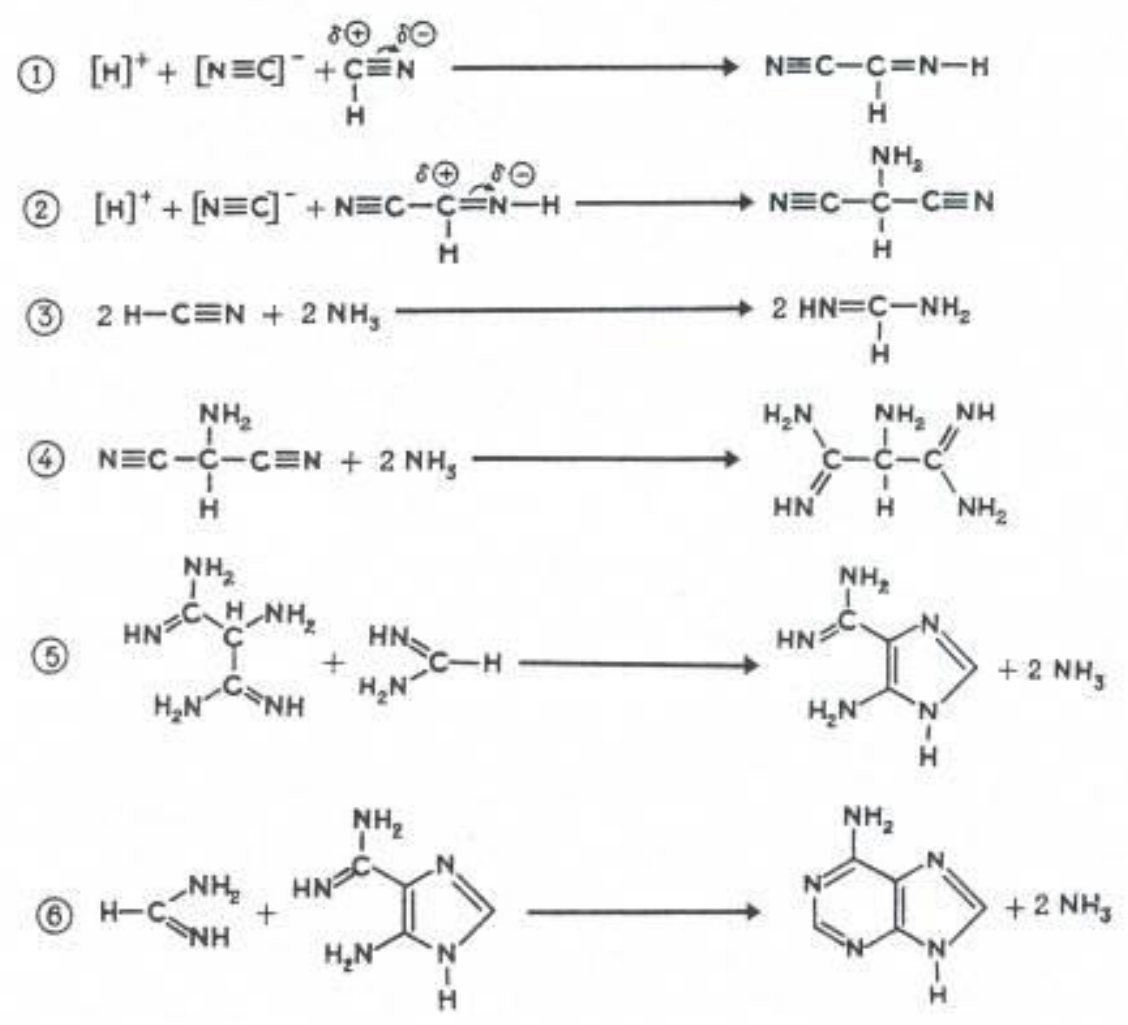

b)

Figure 11: Prospective mechanisms of thermal $\left(+95{ }^{0} \mathrm{C}\right)$ synthesis of purines in aqueous solutions: $\left.a\right)-$ synthesis of hypoxanthine, adenine, guanine and xanthine from 4-aminoimidazole-5-carboxamidine, 4-aminoimidazole-5carboxamide, water, $\mathrm{NH}_{3}$, formamidine and urea; $b$ ) - synthesis of adenine from $\mathrm{NH}_{3}$ and $\mathrm{HCN}$ (total reaction: $5 \mathrm{HCN}=$ adenine)

Under certain conditions in hot mixture of proteinoids in water solutions are formed elementary structures like proteinoid microspheres with diameter 5-10 $\mu \mathrm{m}$ (Nakashima, 1987). Gas electric discharge with color coronal spectral analyses was applied in this type of experiment analogous to S. Miller's experiments (Ignatov \& Tsvetkova, 2011). In S. Miller's experiments one of the basic conditions is electric gas discharge. The analogous experiment was conducted by the authors under laboratory conditions. The first living structures were most probably formed in warm and hot mineral water with more bicarbonate and metal ions $(\mathrm{Na}, \mathrm{Ca}, \mathrm{Mg}$, $\mathrm{Zn}, \mathrm{K}$, etc.). There occurred gas electric discharge (lightning) in the primordial atmosphere close to the water surface. In the course of experiment was used the similar gas coronal electric discharge on water drops placed on the electrode of the device for gas coronal electric discharge formation. Water drops were heated to the boiling point in an electric field of high frequency and voltage and an electric discharge was applied, analogous as in the primordial atmosphere. As a result, an organized structure with a size of $\sim 1.2-1.3 \mathrm{~mm}$ was formed in interelectrode space (Fig. 12). It was formed as a result of the accretion of elementary structures sized of $\sim 5-10$ $\mu \mathrm{m}$ in the biggest structure with size $1.2-1.4 \mathrm{~mm}$ and concentrated in a large structure where the basic electric voltage is applied. 


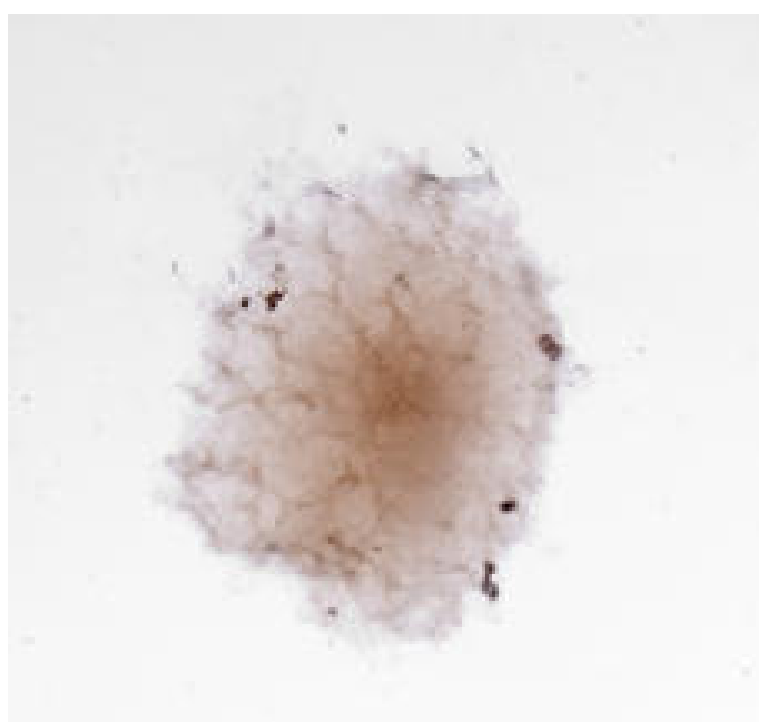

Figure 12: The organized structure in water sample subjected to the temperature $+100{ }^{0} \mathrm{C}$ in the electric field of high voltage and frequency. The material of the electrode - hostafan; electric voltage - $15 \mathrm{kV}$, electric impulse duration - $10 \mu \mathrm{s}$; electric current frequency - $15 \mathrm{kHz}$.

It should be noted that no structure was organized in a control sample of water placed on the electrode. Before its placement on the electrode, the water was heated to the boiling point and then cooled. The structure organization increased with the increase of the duration of the gas electric discharge. Moreover, in experiments was observed formation of small structures and their further "adjoining" to the larger structure. The large structure was preserved with the original size for some time in the absence of electric discharge.

This experiment shows that the organization of structures in water under certain external conditions may take place. In natural conditions water is heated up to $+100{ }^{\circ} \mathrm{C}$ by the magma. The structure formed from heated water was evidently a result of self-organization. Living organisms are complex self-organizing systems. Thermodynamically they belong to the open systems because they constantly exchange substances and energy with the environment. The changes in the open systems are relatively stable in time. The stable correlation between components in an open system is called a dissipative structure. According to I. Prigozhin, the formation of dissipative structures and the elaboration to living cells is related to changes in entropy (Nikolis \& Prigozhin, 1979).

Taking into account these views it may be concluded that the initial stage of evolution, apparently, was connected with formation at high temperature of the mixtures of amino acids and nitrogenous substances analogues of nucleic acids. Such synthesis is possible in aqueous solutions under thermal conditions in the presence of $\mathrm{H}_{3} \mathrm{PO}_{4}$. The next stage is the polycondensation of amino acids into thermal proteinoids at temperatures $65-95{ }^{\circ} \mathrm{C}$. After that stage in a mix of thermal proteinoids in hot water solutions were formed the membrane like structures.

Our data are confirmed by experiments of T. Sugawara (Japan), who in 2011 created the membrane like proto cells from aqueous solution of organic molecules, DNA and synthetic enzymes under temperature close to water's boiling point $+95{ }^{\circ} \mathrm{C}$ (Sugawara, 2011). This data confirm the possibility that first organic forms of life originated in hot water.

\section{Conclusion}

The data obtained testify that origination of life and living matter depends on physical-chemical properties of water and external factors - temperatures, $\mathrm{pH}$, electric discharges and isotopic composition. Hot mineral alkaline water interacting with $\mathrm{CaCO}_{3}$ is most closed to these conditions. Next in line with regard to its quality is seawater. For chemical reaction of dehydration-condensation to occur in hot mineral water, water is required to be alkaline with $\mathrm{pH}$ range 9-11. In warm and hot mineral waters the local maximums in IR-spectra from 8 to 14 $\mu \mathrm{m}$ were more expressed in comparison with the local maximums measured in the same water samples with lower temperature. The content of deuterium in hot mineral water may be increased due to the physical chemical processes of the deuterium accumulation as solar radiation, volcanic geothermal processes and electric discharges in the atmosphere. These natural processes could lead to the enrichment of the hydrosphere by deuterium in the form of $\mathrm{HDO}$ which evaporates more slowly than $\mathrm{H}_{2} \mathrm{O}$, and condenses faster. If the primary hydrosphere really contained HDO, that this may explain the thermal stability of the first organic life forms in the hot mineral water, as the thermal stability of deuterated macromolecules like DNA and proteins in $\mathrm{D}_{2} \mathrm{O}$ 
solutions is somewhat higher than their protonated forms due to the isotopic effects of deuterium.

\section{Acknowledgements}

The authors wish to thank K. Chakarova from Bulgarian Academy of Sciences for registering IR-spectra.

\section{References}

Abelson, P. (1966) Chemical events on the "primitive" earth. Proc. Natl. Acad. Sci. U.S., 55: 1365-1372.

Calvin, M. (1969) Chemical evolution. Oxford: Clarendon, 278 p.

Brubach, J.B., Mermet, A., Filabozzi, A., Gerschel, A. \& Roy, P. (2005) Signatures of the hydrogen bonding in the infrared bands of water. J. Chem. Phys., 122: 184509.

Cioni, P. \& Strambini, G.B. (2002) Effect of heavy water on protein flexibility. Biophysical J., 82(6): 3246-3253.

Eisenberg, D. \& Kauzmann, W. (1969) The Structure and Properties of Water. Oxford University Press, London.

Eryomin, V.A., Chekulayeva, L.N. \& Kharatyan, F.F. (1978) Growth of Micrococcus lysodeikticus on a deuterated medium. Microbiologia, 14: 629-636 [in Russian].

Fox, S.W. \& Krampitz, G. (1964) Catalytic decomposition of glucose in aqueous solution by thermal proteinoids. Nature, 203: 1362-1364.

Fox, S.W. \& Wang, C.T. (1968) Melanocytestimulating hormone: Activity in thermal polymers of alpha-ammo acids. Science, 160: 547-548.

Harada, I. \& Fox, S.W. (1964) Thermal synthesis of natural ammo-acids from a postulated primitive terrestrial atmosphere. Nature, 201: 335-336.

Ignatov, I. (2010) Which water is optimal for the origin (generation) of life? Euromedica, Hanover. pp. 34-37.

Ignatov, I. (2012) Origin of life and living matter in hot mineral water. Conference on the Physics, Chemistry and Biology of Water, Vermont Photonics, USA, 2012. p. 67.

Ignatov, I. \& Tsvetkova, V. (2011) Water for the origin of life and informationability of water. Kirlian (electric images) of different types of water. Euromedica, Hanover, pp. 32-35.

Ignatov, I. \& Mosin, O.V. (2013a) Color coronal (Kirlian) spectral analysis in modeling of nonequilibrioum conditions with the gas electric discharges simulating primary atmosphere. S. Miller's experiments. Naukovedenie, 3(16): 1-15 [in Russian] [Online] Available: URL: http://naukovedenie.ru/PDF/05tvn313.pdf (May 10, 2013).

Ignatov I. \& Mosin, O.V. (2013a) Possible processes for origin of life and living matter with modeling of physiological processes of bacterium Bacillus subtilis in heavy water as model system. Journal of Natural Sciences Research, 3(9): 65-76.

Ignatov, I. \& Mosin, O.V. (2013b) Modeling of possible processes for origin of life and living matter in hot mineral and seawater with deuterium. Journal of Environment and Earth Science, 3(14): 103-118.

Ignatov, I. \& Mosin, O.V. (2013c) Isotopic composition of water and its temperature in the evolutionary origin of life and living matter. Naukovedenie, 1(14): 1-16 [in Russian] [Online] Available: URL: http://naukovedenie.ru/PDF/42tvn113.pdf (February 13, 2013).

Ignatov, I. \& Mosin, O.V. (2013d) Possible processes for origin of life and living matter with modeling of physiological processes of bacterium Basillus subtilis as model system in heavy water. Journal of Natural Sciences Research, 3(9): 65-76.

Ignatov, I. \& Mosin, O.V. (2012) Isotopic composition of water and its temperature in modeling of primordial hydrosphere experiments. Euro-Eco, Hanover, p. 62.

Ignatov, I. \& Mosin, O.V. (2013d) Modeling of possible processes for origin of life and living matter in hot mineral and seawater with deuterium. Journal of Environment and Earth Science, 3(14): 103-118.

Ignatov, I. \& Mosin, O.V. (2013e) Method for colour coronal (Kirlian) spectral analysis. Biomedical Radio Electronics, 1: 38-47 [in Russian].

Kurihara, K., Tamura, M. \& Shohda, K. (2011) Self-Reproduction of supramolecular giant vesicles combined with the amplification of encapsulated DNA. Nature Chemistry, 4(10): 775-781.

Kushner, D.J., Baker, A. \& Dunstall, T.G.. (1999) Pharmacological uses and perspectives of heavy water and deuterated compounds. Can. J. Physiol. Pharmacol., 77(2): 79-88.

Lamprecht, I. Schroeter, D. \& Paweletz, N. (1989) Disorganization of mitosis in HeLa cells by deuterium oxide, European journal of cell biology, 50(2): 360-369.

Linsky, J.L. (2007) D/H and nearby interstellar cloud structures / Ed. J.I. Linsky. Space Science Reviews, NY: Springer Science, Business Media. Vol. 130. 367 p.

Lis, G., Wassenaar, L.I. \& Hendry, M.J. (2008) High-precision laser spectroscopy D/H and ${ }^{18} \mathrm{O} /{ }^{16} \mathrm{O}$ Measurements of microliter natural water samples. Anal. Chem., 80(1): 287-293.

Lobishev, V.N. \& Kalinichenko, L.P. (1978) Isotopic effects of $D_{2} O$ in biological systems. Moscow, Nauka, 215 p. 
Mathews, C.N. \& Moser, R. (1968) Peptide synthesis from hydrogen-cyanide and water. Nature, 215: 12301234.

Max, J.J. \& Chapados, C. (2009) Isotope effects in liquid water by infrared spectroscopy. III. $\mathrm{H}_{2} \mathrm{O}$ and $\mathrm{D}_{2} \mathrm{O}$ spectra from 6000 to $0 \mathrm{~cm}^{-1}$. J. Chem. Phys., 131: 184505.

Miller, S.L. (1953) A production of amino acids under possible primitive Earth conditions. Science, 117(3046): 528-529.

Mosin, O.V. (1996) Studying of methods of biotechnological preparation of proteins, amino acids and nucleosides, labeled with stable isotopes ${ }^{2} \mathrm{H},{ }^{13} \mathrm{C}$ and ${ }^{15} \mathrm{~N}$ with high levels of isotopic enrichment: autoref. disser. thesis PhD: Moscow, M.V. Lomonosov State Academy of Fine Chemical Technology, $26 \mathrm{p}$.

Mosin, O.V., Skladnev, D.A., Egorova, T.A. \& Shvets, V.I. (1996) Mass-spectrometric determination of levels of enrichment of ${ }^{2} \mathrm{H}$ and ${ }^{13} \mathrm{C}$ in molecules of amino acids of various bacterial objects. Bioorganic Chemistry, 22(10-11): 856-869.

Mosin, O.V., Skladnev, D.A. \& Shvets, V.I. (1998) Biosynthesis of ${ }^{2}$ H-labeled phenylalanine by a new methylotrophic mutant Brevibacterium methylicum. Bioscience, biotechnology, and biochemistry, 62(2): 225-229.

Mosin, O.V., Shvets, V.I., Skladnev, D.A. \& Ignatov, I. (2012) Studying of microbic synthesis of deuterium labeled L-phenylalanine by methylotrophic bacterium Brevibacterium Methylicum on media with different content of heavy water. Russian Journal of Biopharmaceuticals, 4(1): 11-22.

Mosin, O.V. \& Ignatov, I. (2012a) Isotope effects of deuterium in bacterial and microalgae cells at growth on heavy water $\left(\mathrm{D}_{2} \mathrm{O}\right)$. Voda: Himia i Ecologija, 3, 83-94 [in Russian].

Mosin, O.V. \& Ignatov, I. (2012b) Studying of isotopic effects of heavy water in biological systems on example of prokaryotic and eukaryotic cells. Biomedicine, Moscow, 1(1-3): 31-50 [in Russian].

Mosin, O.V. \& Ignatov, I. (2013) Microbiological synthesis of ${ }^{2} \mathrm{H}$-labeled phenylalanine, alanine, valine, and leucine/isoleucine with different degrees of deuterium enrichment by the Gram-positive facultative methylotrophic bacterium Brevibacterium methylicum. International Journal of Biomedicine, 3(2), $132-138$.

Mosin, O.V., Ignatov, I., Skladnev, D.A. \& Shvets, V.I. (2014) A strain of Gram-positive facultative methylotrophic bacterium Brevibacterium methylicum - producer of $\left[{ }^{2} \mathrm{H}\right]$ phenylalanine. Drug development \& registration, 1(6): 58-67 [in Russian].

Mosin, O.V. \& Ignatov, I (2014) Biosynthesis of photochrome transmembrane protein bacteriorhodopsin of Halobacterium halobium labeled with deuterium at aromatic amino acids residues of 2,3,4,5,6$\left.{ }^{2} \mathrm{H}_{5}\right] \mathrm{Phe},\left[3,5-{ }^{2} \mathrm{H}_{2}\right] \mathrm{Tyr}$ and $\left[2,4,5,6,7-{ }^{2} \mathrm{H}_{5}\right]$ Trp. Chemistry and Materials Research, 6(3): 38-48.

Mulkidjanian, A.Y. \& Galperin, M.Y. (2009) On the origin of life in the Zinc world. Validation of the hypothesis on the photosynthesizing zinc sulfide edifices as cradles of life on Earth. Biology Direct, 4: 26-28.

Nakashima, T. (1987) Metabolism of proteinoid microspheres / Ed. T. Nakashima. In: Origins of life and evolution of biospheres, 20(3-4), pp. 269-277.

Nikolis, P. \& Prigozhin, I. (1979) Self-organization in non-equilibrium systems. Moscow: Mir, pp. 1-512 [in Russian].

Ponsa, M.L., Quitte G.., Fujii, T. et al. (2011) Early archean serpentine mud volcanoes at Isua, Greenland, as a niche for early life. Proc. Natl. Acad. Sci. U.S., 108: 17639-17643.

Schirber, M. (2010) First fossil-makers in hot water. Astrobiology magazine [Online] Available: URL: http://www.astrobio.net/exclusive/3418/first-fossil-makers-in-hot-water (January 3, 2010).

Somlyai, G., Jancso, G., Jakli, G et al. (2012) Deuterium depletion from tissue culture to human clinical studies. In: $2^{\text {nd }}$ International Congress on Deuterium Depletion. Budapest, Hungary, 17-18 May, 2012.

Sugawara, T. (2011) Self-reproduction of supramolecular giant vesicles combined with the amplification of encapsulated DNA. Nature Chemistry, 1127: 775-780.

Szostak, J.W. (2011) An optimal degree of physical and chemical heterogeneity for the origin of life? Philos. Trans. Royal Soc. Lond. Biol. Sci., 366(1580): 2894-901.

Török, G., Csík, M., Pintér, A. et al. (2000) Effects of different deuterium concentrations of the media on the bacterial growth and mutagenesis. Egészségtudomány/Health Science, 44: 331-338.

Trevors, J.I. \& Pollack, G.H. (2005) Hypothesis: origin of live in hydrogel environment. Progress in biophysics and molecular biology, 89(1): 1-8.

Vertes A. (2003) Physiological Effect of Heavy Water. Elements andIisotopes:Fformation, Transformation, Distribution. Dordrecht: Kluwer Acad. Publ. pp. 111-112.

Yukhnevitch, G.B. (1973) Infrared spectroscopy of water. Moscow, Nauka, 207 p. [in Russian].

Zelsmann, H.R. (1995) Temperature dependence of the optical constants for liquid $\mathrm{H}_{2} \mathrm{O}$ and $\mathrm{D}_{2} \mathrm{O}$ in the far IR region. J. Mol. Struct., 350: 95-114. 
The IISTE is a pioneer in the Open-Access hosting service and academic event management. The aim of the firm is Accelerating Global Knowledge Sharing.

More information about the firm can be found on the homepage:

http://www.iiste.org

\section{CALL FOR JOURNAL PAPERS}

There are more than 30 peer-reviewed academic journals hosted under the hosting platform.

Prospective authors of journals can find the submission instruction on the following page: http://www.iiste.org/journals/ All the journals articles are available online to the readers all over the world without financial, legal, or technical barriers other than those inseparable from gaining access to the internet itself. Paper version of the journals is also available upon request of readers and authors.

\section{MORE RESOURCES}

Book publication information: http://www.iiste.org/book/

Academic conference: http://www.iiste.org/conference/upcoming-conferences-call-for-paper/

\section{IISTE Knowledge Sharing Partners}

EBSCO, Index Copernicus, Ulrich's Periodicals Directory, JournalTOCS, PKP Open Archives Harvester, Bielefeld Academic Search Engine, Elektronische Zeitschriftenbibliothek EZB, Open J-Gate, OCLC WorldCat, Universe Digtial Library, NewJour, Google Scholar

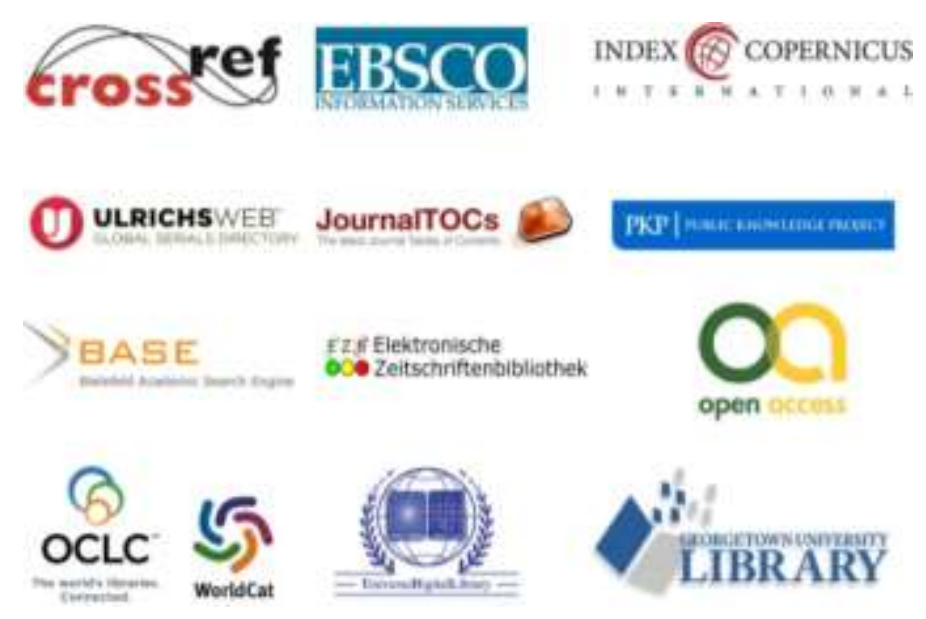

